AperTO - Archivio Istituzionale Open Access dell'Università di Torino

\title{
Adoptive immunotherapy with CAR modified T cells in cancer: current landscape and future perspectives
}

\section{This is the author's manuscript}

Original Citation:

Availability:

This version is available http://hdl.handle.net/2318/1700519

since 2020-10-24T11:29:53Z

Terms of use:

Open Access

Anyone can freely access the full text of works made available as "Open Access". Works made available under a Creative Commons license can be used according to the terms and conditions of said license. Use of all other works requires consent of the right holder (author or publisher) if not exempted from copyright protection by the applicable law. 


\title{
Adoptive immunotherapy with CARs modified T cells in cancer: current landscape and future perspectives
}

\author{
Marta Coscia $^{1,2}$, Candida Vitale ${ }^{1,2}$, Marco Cerrano $^{1,2}$, Enrico Maffini $^{3}$, Luisa Giaccone ${ }^{2,4}$, \\ Mario Boccadoro ${ }^{1,2}$ and Benedetto Bruno ${ }^{2,4}$
}

\section{Affiliations:}

${ }^{1}$ Division of Hematology, University of Torino, A.O.U. Città della Salute e della Scienza di Torino, via Genova 3, 10126 Torino, Italy.

${ }^{2}$ Department of Molecular Biotechnology and Health Sciences, University of Torino, via Nizza 52, 10126, Torino, Italy.

${ }^{3}$ Hematology and stem cell transplant, Romagna Transplant Network, Viale Randi 5, 48121, Ravenna, Italy.

${ }^{4}$ SSD Trapianto allogenico di cellule staminali, Department of Oncology, A.O.U. Città della Salute e della Scienza di Torino, via Genova 3, 10126 Torino, Italy.

M.C. and C.V. contributed equally to this manuscript 
Table of content

1. Abstract

2. Introduction

3. Anti-CD19 CAR T cells

3.1. Currently approved anti-CD19 CAR T cells

3.1.1. Tisagenlecleucel (CTL019, Kymriah ${ }^{\circledR}$ )

3.1.2. Axicabtagene Ciloleucel (KTE-C19, Yescarta ${ }^{\circledR}$ )

3.2. Other anti-CD19 CAR $T$ cell products under development

3.2.1. Lisocabtagene Maraleucel (JCAR017)

\subsubsection{UCART19}

4. Alternative targets for CAR T cells

4.1. Novel T-cell targets for B-cell malignancies

4.3. T-cell targets for non-B-cell lymphoproliferative disorders

4.4. CAR T cells for myeloid diseases

4.5. CAR T cells for solid tumors

5. CAR-T cells related toxicities

5.1. Cytokine release syndrome

5.2. Neurotoxicity

6. Alternative sources and off-the-shelf carriers for CARs

6.1. Post-allogeneic stem cell transplant CAR $T$ cells

6.2. Off-the-shelf allogeneic CAR T cells

6.3. Alternative off-the-shelf CAR carriers

8. Acknowledgement

9. References 


\section{Abstract}

Cellular therapies are a rapidly evolving approach to treat cancer in the light of their unique mechanism of action that potentially overcomes drug resistance and induce durable remissions. Modalities of adoptive cell therapy include gene-modified $\mathrm{T}$ cells expressing novel $\mathrm{T}$ cell receptors (TCR) or chimeric antigen receptors (CAR) that modify the immune system to recognize tumor cells and carry out potent anti-tumor effector functions. CAR $\mathrm{T}$ cells have shown very promising clinical results and several trials are being conducted worldwide to establish their role in cancer treatment. Most successful results have been observed in lymphoproliferative disorders with the use of CD19-directed CAR T cells that led to their commercial approval by FDA. In this review, we provide a comprehensive overview of the current role of CAR T cell therapies in hematological malignancies and solid tumors, their associated toxicities and potential future developments in the armamentarium for cancer treatment.

\section{Introduction}

Chimeric antigen receptors (CARs) are genetically constructed hybrid receptors that consists of a single-chain variable fragment ( $\mathrm{scFv}$ ) of a monoclonal antibody as the antigen-binding extracellular domain, an intracellular $\mathrm{CD} 3 \zeta$ chain as the $\mathrm{T}$ cell receptor (TCR) signaling domain, and an additional co-signaling domain, mainly CD28 and 4-1BB, to deliver co-stimulation $(1,2)$. Several methods to transfer CARs to T cells have been evaluated and the current most commonly used approach is transfer by retroviral infection (3). Cytotoxic activity of CAR $\mathrm{T}$ cells is determined by antigen-binding to the $\mathrm{scFv}$, leading, in turn, to phosphorylation of $\mathrm{CD} 3 \zeta$ and additional signaling cascades by co-stimulating domains (4). This mechanism reproduces effects similar to signaling following $\mathrm{T}$ cell activation through the TCR complex. Importantly, CAR T cells recognize target antigens in an MHC-independent fashion. Since their first discovery in the late 1980s $(5,6)$, CAR T cells have undergone major improvements and most clinical trials have been carried out in hematological malignancies such as B cell non Hodgkin lymphomas (NHL) and acute lymphoblastic leukemias (ALL). CD19 was shown to be an ideal target (7-9) given its expression from the early stages of B cell development up to plasma cell differentiation. In 2003, Sadelain et al. at the Memorial Sloan Kettering Cancer Center, New York, US, were the first to show successful transduction of lymphocytes with CD19 CARs that could lead to tumor reduction and even eradication in immunodeficient mouse models with various B cell malignancies (10). CARs engineering has dramatically evolved over time resulting in four generations of CAR constructs (Figure1). Second generation CAR T cells carry the costimulatory domains CD28 (11) or 4-1BB (12) and have been the most commonly used constructs in clinical studies. The first clinical trial to show clinically significant responses was performed by Sadelain and co-workers in 2013 in patients with ALL (13). Since then, most research with CAR $\mathrm{T}$ cell therapies has been performed in hematological malignancies, but CAR T cell technology is being explored in solid tumors, however achieving limited 
clinical activity thus far. Major toxicities of CAR T cells include cytokine release syndrome and neurotoxicity that though reversible can be severe and life-threatening. In this review, we provide a comprehensive overview of the current role of CAR T cell therapies in hematological malignancies and solid tumors, their associated toxicities and potential future developments in the armamentarium of cancer treatment.

\section{Anti-CD19 CAR T cells}

The constant and stable expression of CD19 on neoplastic cells in most B-cell malignancies makes it an ideal target for CAR T cell therapy. CD19 is not expressed on normal tissues besides B cells, thus theoretically limiting off-tumor on-target toxicities to B cell aplasia. CAR T cell products against CD19 are currently the most advanced in terms of clinical development and results of clinical trials. As of November 2018, two anti-CD19 CAR T cell products were approved by US Food and Drug Administration (FDA) and by European Medicine Agency (EMA). Other constructs are already in an advanced phase of clinical investigation (Table 1).

\subsection{Currently approved anti-CD19 CAR $T$ cells}

\subsubsection{Tisagenlecleucel (CTL019, Kymriah $\left.{ }^{\circledR}\right)$}

CTL019 (formerly known as CART19) engineered T cells express a chimeric antigen receptor which consists of an extracellular anti-CD19 scFv, a CD8 hinge and transmembrane domain, a CD3 $\zeta$ domain providing T-cell activation, and a 4-1BB (CD137) domain as costimulatory molecule. A high degree of in vivo expansion of CTL019 cells that resulted in complete remission (CR) in two children with refractory B-cell ALL was initially reported at Children's Hospital of Philadelphia and at University of Pennsylvania (9). In a single-center phase I/IIa study, 25 young patients (age range 5 to 22 years) and 5 older patients (age range 26 to 60 years) were treated (14). After leukapheresis, interim therapy at the discretion of the treating physician was allowed. Morphologic CR at one-month assessment was observed in $90 \%$ of patients, and 6-month event-free survival (EFS) was $67 \%$. All patients developed cytokine release syndrome (CRS), which was severe in $27 \%$, and usually associated with a higher disease burden. CRS was effectively managed with supportive measures and the administration of anti-cytokine therapy, including the IL-6 receptor antagonist tocilizumab.

A following phase II multicenter study with tisagenlecleucel was conducted in pediatric and young adult patients with CD19+ relapsed or refractory B-cell ALL (15). Before tisagenlecleucel infusion, 96\% of patients received lymphodepleting chemotherapy, which was omitted at the investigator's discretion in case of leukopenia. Median weight-adjusted dose of transduced viable T cells was $3.1 \times 10^{6} / \mathrm{kg} /$ body weight. Seventy-five patients received a single infusion of tisagenlecleucel, with an overall response rate (ORR) of $81 \%$, including $60 \% \mathrm{CR}$ and $21 \% \mathrm{CR}$ with incomplete hematologic 
recovery. Persistence of tisagenlecleucel in the blood was observed for as long as 20 months. Six-month EFS was 73\%, and 12-month EFS was 50\%. Eight patients underwent allogeneic hematopoietic stemcell transplantation (alloHSCT) while in remission. Overall survival (OS) for the whole cohort was 90\% and $76 \%$ at 6 and 12 months after infusion respectively. Seventy-three $\%$ of patients developed grade $\geq 3$ adverse events which were attributable to tisagenlecleucel, mainly occurring within 8 weeks after infusion. Most common non-hematologic adverse events of any grade were CRS (77\%, 48\% treated with tocilizumab), pyrexia (40\%), decreased appetite (39\%), febrile neutropenia (36\%), and headache (36\%). For CRS, median time to onset was 3 days and median duration was 8 days. Neurologic events occurred in $40 \%$ of patients within 8 weeks after infusion (13\% grade 3 , no grade 4 ), and no cerebral edema was reported. Two deaths occurred within 30 days after tisagenlecleucel infusion: one patient died from cerebral hemorrhage, and one patient from progressive B-cell ALL.

CTL019 was also evaluated in the setting of CD19+ B-cell lymphomas. A trial conduced at the University of Pennsylvania enrolled patients with relapsed/refractory diffuse large B-cell lymphoma (DLBCL) or follicular lymphoma (FL) (16). Bridging therapy was allowed and lymphodepleting regimen was at the investigator's discretion. Twenty-eight patients were infused (DLBCL $n=14$, FL $\mathrm{n}=14$ ), with a median CTL019 cell dose of $5.79 \times 10^{6} / \mathrm{kg} /$ body weight. T-cell manufacturing was unsuccessful for 5 patients. ORR at 3 months was $64 \%, 50 \%$ for DLBCL and 79\% for FL respectively. CR at 6 months was observed in 57\% of patients (43\% DLBCL, 71\% FL). At a median follow-up of 28.6 months, $57 \%$ of patients were progression-free (43\% DLBCL, 70\% FL). Among 16 patients in CR, 14 had consistently detectable levels of CTL019 DNA between 6 and 24 months after infusion. Severe CRS was observed in 5 patients with no CRS-related deaths, one patient was treated with tocilizumab, no patients received glucocorticoids. Neurologic toxic effects were reported in 11 patients, and 3 had grade $\geq 3$ encephalopathy.

A following multicenter phase II trial (JULIET) enrolled adult patients with relapsed/refractory DLBCL (17). The apheresis product was cryopreserved, and bridging chemotherapy was allowed (eventually given to $90 \%$ of patients). As lymphodepleting chemotherapy, patients received fludarabine $25 \mathrm{mg} / \mathrm{m}^{2}$ and cyclophosphamide $250 \mathrm{mg} / \mathrm{m}^{2}$ for 3 days, or bendamustine $90 \mathrm{mg} / \mathrm{m}^{2}$ for 2 days. Preliminary results on 81 patients showed an ORR of $53.1 \%$, with $39.5 \% \mathrm{CR}$ and $13.6 \%$ partial responses (PR). Three-month CR rate was 32\%, and 6-month CR rate was 30\% (for 46 evaluable patients). At 6 months, the probability of OS was $64.5 \%$. Grade 3 or 4 adverse events were observed in $86 \%$ of patients, and no deaths were attributed to CTL019. CRS occurred in $58 \%$ of patients ( $15 \%$ grade $3,8 \%$ grade 4$), 15 \%$ of whom received tocilizumab, and $11 \%$ corticosteroids. Neurologic adverse events were reported in $12 \%$ of patients.

Tisagenlecleucel is currently approved in the US and in Europe for the treatment of patients up to 25 years of age with refractory B-cell precursor ALL, in second relapse or beyond, and for adult patients with relapsed or refractory large B-cell lymphoma (including DLBCL, high grade B-cell lymphoma and DLBCL arising from FL) after two or more lines of systemic therapy. 
Other CD19+ lymphoproliferative diseases can also be targeted by CTL019. As previously described, the pivotal trial at the University of Pennsylvania evaluated its efficacy in patients with relapsed/refractory FL with encouraging response rates (16). A multicenter study is expected to start recruitment soon (NCT03568461). Fourteen patients with heavily pretreated chronic lymphocytic leukemia (CLL) were administered CTL019 in a single center pilot study (18). ORR was $57 \%$, with a CR rate of 29\%. Patients in CR showed persistent responses with a median duration of 40 months. Nine patients developed CRS, and 5 showed concurrent neurologic symptoms. In multiple myeloma (MM), the combination of CTL019 with high-dose melphalan and autologous stem cell transplantation (ASCT) in 10 patients, who had previously undergone ASCT with poor response, was investigated (19). The regimen was defined safe and feasible, with most toxicity attributable to ASCT without severe CRS. Two patients showed significantly longer progression-free survival (PFS) compared with that obtained after ASCT. Tisagenlecleucel is currently under evaluation in pediatric NHL patients (NCT03610724), and in combination with anti-PD-1 monoclonal antibody pembrolizumab for the treatment of relapsed/refractory DLBCL (NCT03630159). In the B-cell ALL setting, the OBERON study (NCT03628053) will compare tisagenlecleucel with blinatumomab or inotuzumab in adult patients.

\subsubsection{Axicabtagene Ciloleucel (KTE-C19, Yescarta®)}

KTE-C19 construct, developed at the National Cancer Institute, consists of an extracellular anti-

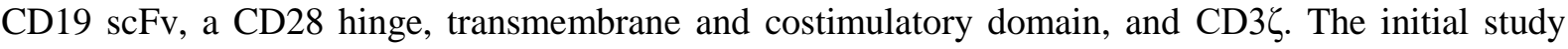
showed its feasibility in patients with refractory DLBCL and indolent B-cell malignancies with a response in 12/15 patients, of whom 8 reached CR (20). A following trial on 22 patients with advancedstage lymphoma demonstrated the feasibility of a reduced dose of lymphodepleting chemotherapy (cyclophosphamide 300 or $500 \mathrm{mg} / \mathrm{m}^{2}+$ fludarabine $30 \mathrm{mg} / \mathrm{m}^{2}$ both for 3 days vs cyclophosphamide 120 or $60 \mathrm{mg} / \mathrm{kg}$ + fludarabine $25 \mathrm{mg} / \mathrm{m}^{2}$ for 5 days) (21). The possibility of centralized manufacturing of the product led to the design of multicenter trials. Feasibility and safety were demonstrated in the phase I ZUMA-1 trial, where 4/7 patients with heavily pre-treated refractory DLBCL achieved CR at 1 month (22). The phase II portion of the ZUMA-1 trial enrolled patients with refractory DLBCL (cohort 1) and primary mediastinal B-cell lymphoma or transformed FL (cohort 2) (23). CAR T cells manufacturing was successful in $99 \%$ of patients. The conditioning chemotherapy consisted of fludarabine $30 \mathrm{mg} / \mathrm{m}^{2}+$ cyclophosphamide $500 \mathrm{mg} / \mathrm{m}^{2}$ on days $-5,-4$, and -3 before the CAR $\mathrm{T}$ cell administration, and systemic bridging chemotherapy was not allowed. Target dose of CAR T cells was $2 \times 10^{6} / \mathrm{kg} /$ body weight. Axicabtagene ciloleucel was administered to 101 patients, with an objective response rate of $82 \%$ and a $54 \% \mathrm{CR}$ rate which was consistent across major covariates. Responses were durable: among patients with a $\geq 1$-year follow up $(n=108), 42 \%$ maintained the response at the data cutoff, including $40 \%$ with CR. Of note, 3 patients on the phase I study had an ongoing CR at 24 months. Ninety-five $\%$ of patients developed grade $\geq 3$ adverse events, including grade $\geq 3$ neutropenia in $78 \%$, grade $\geq 3$ anemia in $43 \%$, and grade $\geq 3$ thrombocytopenia in $38 \%$. CRS occurred in $93 \%$ of patients, 
mostly of low grade (grade $137 \%$, grade $244 \%$, grade $\geq 313 \%$, including one death related to hemophagocytic lymphohistiocytosis). Another patient who developed CRS died from a cardiac arrest, and a third one died of pulmonary embolism. Neurologic adverse effects were reported in $64 \%$ of patients, $28 \%$ being grade $\geq 3$. Tocilizumab was given to $43 \%$ of patients and glucocorticoids to $27 \%$. Axicabtagene ciloleucel is currently approved in the US for the treatment of adult patients with relapsed/refractory large B-cell lymphoma after two or more lines of systemic therapy (including DLBCL not otherwise specified, primary mediastinal large B-cell lymphoma, high grade B-cell lymphoma, and DLBCL arising from FL), and in Europe for adult patients with relapsed or refractory DLBCL and primary mediastinal large B-cell lymphoma.

Other CD19+ lymphoproliferative histologies were included in the initial studies with KTEC19. Axicabtagene ciloleucel is currently under investigation for the treatment of mantle cell lymphoma (NCT02601313), CLL (NCT03624036), and other indolent NHL (NCT03105336). Additionally, the combination of axicabtagene ciloleucel with the anti-PD-L1 monoclonal antibody atezolizumab (NCT02926833) and with the anti-4-1BB monoclonal antibody utomilumab (NCT03704298) are under evaluation in refractory large B-cell lymphoma. As part of the development program, KTE-C19 is also under investigation for the treatment of B-cell ALL. The phase I/II ZUMA-3 trial (NCT02614066) is evaluating KTE-C19 in adult patients with relapsed/refractory B-precursor ALL. KTE-C19 are infused after a lymphodepletion consisting of fudarabine $25 \mathrm{mg} / \mathrm{m}^{2}$ for 3 days and cyclophosphamide $900 \mathrm{mg} / \mathrm{m}^{2}$ for one day. Sixteen patients were treated and one experienced a grade 5 event of CRS. Grade $\geq 3$ CRS and neurologic events were reported in $25 \%$ and $63 \%$ of patients, respectively. Eleven patients were evaluable for efficacy, with an ORR of $82 \%$ (73\% CR or CR with partial hematopoietic recovery) (24). KTE-C19 also is under evaluation in pediatric/adolescent patients with relapsed/refractory B-cell ALL in the phase I/II ZUMA-4 trial (NCT02625480).

\subsection{Other anti-CD19 CAR $T$ cell products under development}

\subsubsection{Lisocabtagene Maraleucel (JCAR017)}

JCAR017 construct was developed at the Fred Hutchinson Cancer Research Center. It is composed by an extracellular anti-CD19 scFv, a IgG4 hinge domain, a CD28 transmembrane domain, a $\mathrm{CD} 3 \zeta$ activation domain, and a 4-1BB costimulatory domain.

Based on preclinical work in a mouse model showing that different $\mathrm{T}$ cell subsets are transduced efficiently but differ in their effector functions, and that CAR T products composed of defined T-cell subsets can have an increased potency (25), investigators led a phase I clinical trial using a predefined 1:1 CD4:CD8 T cell ratio for the treatment of CD19+ B cell malignancies (with an enrichment of CD8+ central memory $\mathrm{T}$ cells, when feasible). Thirty-two patients with different relapsed/refractory B-cell NHL (mainly DLBCL and transformed large cell lymphoma), including patients relapsed after ASCT or alloHSCT, were treated (26). Different lymphodepleting regimens were allowed, and cells were 
infused at a dose of $2 \times 10^{5} / \mathrm{kg}, 2 \times 10^{6} / \mathrm{kg}$, or $2 \times 10^{7} / \mathrm{kg}$. ORR was $63 \%$, with a CR rate of $33 \%$. CRS was detected in $13 \%$ of patients, and $28 \%$ had grade $\geq 3$ neurotoxicity. Thirty patients with relapsed or refractory CD19+ B-cell ALL were also treated with the same regimen, and 93\% achieved a bone marrow remission, as determined by flow cytometry (27). Eighty-three\% of patients developed CRS, and $50 \%$ had severe neurotoxicity. There were 2 deaths due to toxicity, one related to CRS, and the second to neurotoxicity. The TRANSCEND-001 multicenter trial is testing JCAR017 in relapsed/refractory B cell lymphomas, including DLBCL, transformed FL, grade 3B FL, mantle cell lymphoma, and primary mediastinal B cell lymphoma (28). Bridging therapy is allowed, lymphodepleting chemotherapy consists of fludarabine $30 \mathrm{mg} / \mathrm{m}^{2}$ and cyclophosphamide $300 \mathrm{mg} / \mathrm{m}^{2}$ for 3 days, and different dose levels of infused cells are tested. Preliminary data from the DLBCL cohort $(n=69)$ showed ORR of $49 \%$ and $40 \%$ at 3 and 6 months, respectively, with $40 \%$ and $37 \%$ CR at 3 and 6 months, respectively. CRS was reported in $30 \%$ of patients, with a single grade 4 event. Neurotoxicity developed in $20 \%$ of patients, including $14 \%$ with grade 3-4 events. No deaths were attributable to CRS or neurotoxicity. A randomized phase III trial will evaluate JCAR017 compared to standard of care in adult patients with high-risk transplant-eligible relapsed/refractory aggressive B-cell NHL (NCT03575351). The PLATFORM trial will evaluate JCAR017 in relapsed/refractory aggressive Bcell lymphomas, in combination with different agents such as anti-PD-L1 monoclonal antibody durvalumab, or the new generation immunomodulatory drug CC-122 (NCT03310619). JCAR017 is also currently under evaluation for the treatment of patients with relapsed/refractory CLL (NCT03331198).

\subsubsection{UCART19}

In the attempt to overcome manufacturing issues, particularly occurring in heavily pre-treated patients, universal anti-CD19 CAR T products, derived from healthy donor cells, are currently under development. UCART19 express an anti-CD19 scFv-4-1BB-CD3 $\zeta$ molecule, and is also modified to lack both CD52 expression (in order to render these cells resistant to anti-CD52 monoclonal antibody alemtzumab) and the endogenous TRAC locus (to prevent UCART exhaustion), and to include a RQR8 "safety switch" (allowing targeted elimination through anti-CD20 monoclonal antibody rituximab) (29). After the initial results reported in two young patients with B-cell ALL who achieved molecular remissions ahead of alloHSCT (29), a phase I trial in pediatric patients with high risk relapsed refractory CD19+ B-cell ALL was initiated. Patients receive a lymphodepleting treatment consisting of cyclophosphamide and fludarabine with or without alemtuzumab, following the infusion of $2 \times 10^{7}$ total cells, with the aim of achieving molecular remission and proceeding to alloHSCT. All the first 5 children who were treated achieved CR with incomplete blood count recovery, and were able to proceed to alloHSCT, and 2 of them remain in molecular remission 2 and 2.5 months post-transplant (30). All patients experienced reversible CRS, 2 patients presented mild neurological symptoms that recovered without treatment, and grade 1 acute skin graft-versus-host disease was reported in 2 patients. UCART19 
is also currently under investigation for the treatment of adult patients with relapsed/refractory B-cell ALL (NCT02746952).

\section{Alternative targets for CAR T cells}

\subsection{Novel T-cell targets for B-cell malignancies}

Although highly and uniformly expressed on B cell malignancies, CD19 may be downregulated or mutated in tumor cells (31), and antigen loss variants have been reported as responsible of the majority (70\%) of relapses in ALL (32). Alternative surface molecules, including CD20, CD22 and the immunoglobulin light chain are also frequently expressed in B cell tumors and CARs targeting these alternative lymphoma-associated antigens are currently under development for the treatment of B-cell malignancies (Table 2). Successful results obtained with anti-CD20 monoclonal antibodies, have formally supported the development and clinical testing of anti-CD20 CAR-T cell therapy. CD20 has been targeted with a third generation $\mathrm{CD} 28 / 4-1 \mathrm{BB} / \mathrm{CD} 3 \zeta \mathrm{CAR}$ and transient responses were observed in 3 of 4 patients (33). Inclusion of dual costimulatory domains (CD28 and 4-1BB) enhanced anti-CD20 CAR T cells persistence in patients with indolent B cell and mantle cell lymphoma (34). In this study, anti-CD20 CAR T cells could be detected up to one year post transfer, and 2/3 patients treated had a PFS at 24-month follow up. Based on preclinical results showing their antitumor efficacy, anti-CD22 CAR T cells are currently under evaluation in early-phase clinical trials. Results from a phase I trial testing anti-CD22 CAR $\mathrm{T}$ cells in 21 children and adults with B-cell ALL, including 15 patients previously treated with anti-CD19 CAR T cells, showed a dose-dependent anti-leukemic activity, with CR obtained in $73 \%$ (11/15) of patients - including 5 of 5 patients with CD19 dim or CD19- B-ALL - and a median remission duration of 6 months (35).The immunglobulin kappa (k) light chain antigen is another attractive target because its expression on k-restricted B-cell lymphomas, and not on nonmalignant B cells, may avoid complete B-cell aplasia and minimize humoral immunity impairment. In a phase I clinical trial, 16 patients with relapsed or refractory k+ NHL/CLL or MM were treated with autologous $\mathrm{T}$ cells genetically modified to express a CAR specific for the $\mathrm{k}$ light chain (36). Overall, of 9 patients with relapsed NHL or CLL, 2 achieved a CR remission and one a PR. Of 7 patients with MM, 4 had stable disease (SD) lasting 2-17 months. No toxicities attributable to anti-k-light chain CAR T cells were observed. Another potential tumor antigen is the receptor tyrosine kinase-like orphan receptor (ROR1), a transmembrane glycoprotein expressed on embryonal tissue and aberrantly on many adult malignant tissues, such as B-cell tumors (e.g. CLL, mantle cell lymphoma, B-cell ALL) and numerous types of solid tumors (37-40). Due to its high-level surface expression as well as to its crucial role in tumor cell proliferation, survival, and metastasis, a number of pharmacological agents targeting ROR1 are under development, such as humanized monoclonal antibodies, small molecule inhibitors, bispecific T-cell engagers (BiTE) and anti-ROR1 CAR T cells (41-43). ROR1-targeted T cells have demonstrated 
to generate cytotoxicity against human ROR1 positive B cell malignancies in preclinical studies (39), without causing overt cytotoxicity in non-human primates (44).

\subsection{T-cell targets for multiple myeloma}

Novel cell therapies and several potential targets for CAR T cells are under investigation in MM $(45,46)$ (Table 2). Anti-CD38 and anti-SLAMF7 CAR T cells showed anti-MM effects in preclinical models $(47,48)$, but the expression of both target antigens on other normal tissues including hematopoietic lineages and immune effector cells may cause off-tumor toxic effects limiting their longterm clinical use. Being expressed on plasma cells of all MM patients but not on normal tissues, BCMA - a member of the TNF receptor family - is at present the most promising target in this disease setting. A first in-human phase I clinical trial conducted at the National Cancer Institute in heavily pre-treated MM patients demonstrated the safety and efficacy of adoptively transferred autologous $\mathrm{T}$ cells transduced with a retroviral vector incorporating an anti-BCMA scFv, a CD28 costimulatory domain, and the CD3 $\zeta$ T-cell activation domain. Updated results from this study showed an ORR of $81 \%$, with $63 \%$ very good partial response or CR, and a median EFS of 31 weeks (49). Another phase I study, conducted at the University of Pennsylvania, is currently exploring a different CAR, developed in collaboration with Novartis and consisting of a fully human anti-BCMA scFv with a 4-1BB costimulatory domain that was packaged in a lentiviral vector (50). Three cohorts have been enrolled sequentially, with the aim of collecting preliminary data about safety, efficacy, and kinetics of expansion - both with and without lymphodepleting chemotherapy. Preliminary results presented at 2017 ASH meeting showed that, based on IMWG criteria, in cohort 1 (CAR T cells alone at a dose of $1-5 \times 10^{8}$ cells, n=9) 6/9 pts responded, with 1 ongoing sCR at 21 months, and other responses lasting 1.5 to 5 months. In cohort 2 (cyclophosphamide $1.5 \mathrm{~g} / \mathrm{m}^{2}$ with $1-5 \times 10^{7}$ CAR T cells, $\mathrm{n}=5$ ), $2 / 5 \mathrm{pts}$ responded but progressed at 4 and 2 months, respectively. In cohort 3 (cyclophosphamide $1.5 \mathrm{~g} / \mathrm{m}^{2}$ with $1-5 \times 10^{8} \mathrm{CAR}$ $\mathrm{T}$ cells, $\mathrm{n}=10$ ), the incorporation of cyclophosphamide with the higher dose of CAR T cells led to a disease response in 5/6 patients, and one was not yet evaluable at the time of data submission. Berdeja et al. reported updated data about the dose-escalation portion of a third BCMA CAR T-cell trial (NCT02658929) at the 2017 ASH meeting (51). This was a multicenter study sponsored by Bluebird Bio, which used a second-generation CAR called bb2121 that contained a murine anti-BCMA scFv (the same one used in the National Cancer Institute trial), a 4-1BB costimulatory domain, transduced by a lentiviral vector. Preliminary data from this phase I study showed that $89 \%$ of patients treated with bb2121 responded to treatment with 8 ongoing clinical responses at 6 months, and one patient demonstrating a sustained response beyond one year. Based on these promising results, two phase II multicenter studies evaluating the efficacy and safety of bb2121 in subjects with relapsed/refractory MM are currently ongoing in the US and in Europe (NCT03361748 and NCT03601078). Of note, BCMA is also expressed in a substantial number of lymphoma samples, as well as primary CLL B cells. 
Preclinical data have shown that treatment with bb2121 results in rapid and sustained elimination of the tumors and $100 \%$ survival in NOD/SCID gamma mouse models of human lymphomas, thus supporting the further development of anti-BCMA CAR T cells as a potential treatment for not only MM but also some lymphomas (52). Preliminary results from a fourth anti-BCMA CAR T cells trial, conducted by Nanjing Legend Biotech in China in relapsed/refractory MM patients, were reported at the 2017 American Society of Clinical Oncology Annual Meeting (53). This CAR, called LCAR-B38M, uses a novel antigen-binding domain that binds BCMA at two separate epitopes. At the time of presentation, $100 \%$ (19/19) of patients experienced a response, including $74 \%$ with a CR. During a median followup time of 6 months, no patient with CR experienced relapse. Toxicity was modest: $83 \%$ developed CRS, but only $6 \%$ had grade 3 CRS and no grade 3-4 neurotoxicity was seen. Several additional antigens are currently under investigation in MM as potential targets for CAR T cell therapies, including CD44v6 (54), Lewis Y (55), NKG2D ligands (56), CD229 (57), and integrin $\beta 7$ (58).

\subsection{T-cell targets for non-B-cell lymphoproliferative disorders}

Broadening of CAR T cells to treat T-cell malignancies has proven challenging, mainly because many targetable antigens are also expressed on normal $\mathrm{T}$ lymphocytes. This shared antigenicity can cause fratricide in CAR T cells, inhibiting their proliferation and viability, and leading to normal $\mathrm{T}$ cells depletion and deep impairment of host immunity. To avoid this drawback, an anti-CD5 CAR transduced into a human NK cell line was tested (59). This approach showed potent anti-tumor activity against a variety of T-cell leukemia and lymphoma cell lines as well as primary tumor cells, and was able to demonstrate significant inhibition of disease progression in xenograft mouse models of T-cell ALL. Recent data reported by Gomes-Silva et al. showed that targeted disruption of the CD7 gene using clustered, regularly interspaced short palindromic repeats (CRISPR)/Cas9 prior to CAR expression minimizes fratricide in $\mathrm{T}$ cells and allows the expansion of the CD7-knockout (CD7KO) anti-CD7 CAR $\mathrm{T}$ cells with robust antitumor properties in preclinical models (60). An alternative strategy to limit fratricide is to employ $\mathrm{T}$ cells transduced with a CAR specific for the T-cell receptor (TCR) $\beta$ chain constant region expressed by the malignant cells (i.e. TCRBC1 or TCRBC2), thus sparing the normal $\mathrm{T}$ cells that express the alternative TCRBC chain. Recent data demonstrated that ex vivo selected TCRBC2-positive $\mathrm{T}$ cells transfected with a CD28/OX40/CD3 $\zeta$ anti-TCRBC1 CAR specifically recognized TCRBC1-positive $\mathrm{T}$ cell leukemia and lymphoma cells in vitro and in xenograft murine models (61).

Promising results and limited toxicities obtained with toxin-conjugated CD30-specific monoclonal antibodies (such as brentuximab vedotin) $(62,63)$ have encouraged the development and clinical testing of CD30-directed CAR T cell therapies in Hodgkin lymphoma (HL) and anaplastic large cell lymphoma (ALCL) (Table 2). The clinical efficacy of this approach in relapsed or refractory HL patients was first demonstrated by results obtained in a phase I study conducted in China, which tested 
the adoptive transfer of autologous $\mathrm{T}$ cells transfected with a lentiviral vector encoding for a second generation CAR containing an anti-CD30 scFv combined with a 4-1BB costimulatory domain (64). Within this study, CART-30 cell infusion was well tolerated, with grade $\geq 3$ toxicities occurring only in 2 of 18 patients, and effective, with 7 patients achieving PR and 6 achieving SD. Promising results were obtained by a second phase I dose-escalation study evaluating the safety of autologous $\mathrm{T}$ cells genemodified with a retroviral vector to express an anti-CD30 CAR combined with the CD28 costimulatory domain (65). In this study, of 7 patients with relapsed HL, one entered CR lasting more than 2.5 years after the second infusion of anti-CD30 CAR T cells, one remained in continued CR for almost 2 years, and 3 had transient SD. Of 2 patients with ALCL, one had a CR that persisted 9 months after the fourth infusion of anti-CD30 CAR T cells. No toxicities were observed and even though CD30 may also be expressed by normal activated $\mathrm{T}$ cells, no patients developed impaired virus-specific immunity. These studies demonstrate that targeting CD30 with CAR T cells is safe and can have antitumor activity in CD30+ malignancies.

\subsection{CAR $T$ cells for myeloid diseases}

Despite the increasing availability of new targeted molecules, including IDH, FLT3 and BCL2 inhibitors, the prognosis of relapsed and refractory acute myeloid leukemia (AML) remains dismal. AlloHSCT is the only realistic curative option but it is not feasible in many patients and results are unsatisfactory in this setting, especially if a good quality remission is not achieved before transplantation (66). Despite considerable efforts, the development of CAR T cells in AML represents a major challenge mainly due to the absence of a leukemia-specific surface antigen (67) (Table 2). First, the co-expression of AML antigens on extra-hematopoietic tissues (e.g. CD33 in hepatic Kupffer cells, CD123 on endothelial cells) poses important safety concerns. Besides, currently known AML surface targets are also expressed on normal hematopoietic stem and progenitor cells (HPSCs), leading to a very high risk of severe hematologic toxicities. Given that a long-term pan-myeloablation following AML-directed CAR T cells infusion may not be tolerable, unlike B cell aplasia due to CD19-targeted therapy, different solutions are being tested (68). AlloHSCT represents the logical rescue strategy, but the persistence of even a few CAR T cells after transplantation could lead to graft rejection (67). Therefore, some groups explored the possibility of developing short-term living CAR T cells as a "bridge to transplant". The University of Pennsylvania employed for this purpose CAR mRNA electroporation, in order to allow transient expression of their anti-CD123 CAR as opposed to the stability obtained by viral delivery (69). Unfortunately, this strategy was unsuccessful, since none of the 7 patients enrolled in the clinical trial showed a response, likely due to the lack of CAR T cells persistence (70). As a matter of fact, a prolonged CAR T cells expansion is essential to obtain a sustained remission (15), and finding the right balance between the benefits of CAR persistence and the risks of long-term myelosuppresion is one of the major challenge in AML-directed CAR T cells development. Alternative ways of CAR T cells 
termination, including the use of antibodies against both artificially expressed and constitutively present surface antigens (71), inducible suicide genes (72) and on-off switch strategies (73) are being explored and could permit to promptly induce CAR T cells exhaustion when needed.

The University of Pennsylvania group recently presented another innovative way to prevent the risk of prolonged myelotoxicity and graft rejection due the lack of specificity of CARs in AML. The investigators generated CD33-deficient human HSPCs and demonstrated prolonged engraftment and normal differentiation in mouse and macaque models. CD33-deficient cells were unaffected by antiCD33 CAR T cells, thus allowing for effective anti-leukemic activity without myelotoxicity (74).

With the aim of identifying new specific antigens, Perna et al. performed an exploratory study by combining proteomics and transcriptomics analysis from malignant and normal tissues. Albeit no antigen with characteristics as favorable as CD19 was found, some promising targets, namely ADGRE2, CCR1, CD70, and LILRB2, were identified (75). Besides, a recent proof-of-concept publication showed that also intracellular peptides can be targeted and that the efficacy of CAR T cells can be boosted by vaccination. The authors developed a CAR specific to a WT1/human leukocyte antigen (HLA)-A complex, and vaccination with dendritic cells loaded with the corresponding antigen led to CAR T cells expansion and activation, thus enhancing anti-leukemic activity in a xenograft model (76).

An alternative approach to prevent antigen escape-mediated relapses and off target side effects, is the development of CAR $\mathrm{T}$ cells targeting two different antigens on the leukemic cells (77). These constructs appear of particular interest in AML, due to the impressive clonal heterogeneity and the lack of highly specific antigens, and in this context leukemia stem cells markers are particularly attractive as potential co-targets (78).

Some groups are also testing small molecules with the aim of improving CAR T cells efficacy. Jetani and colleagues recently reported that the FLT3 inhibitor crenolanib had a synergist activity with FLT3directed CAR T cells in a FLT3-ITD AML model, at least in part by increasing FLT3 surface expression (79) and similar results were also presented for midostaurin (80). Besides, it was recently reported that PI3K inhibition can enhance CD33-directed CAR T cells durability, thus improving antitumor activity (81). Despite many in vitro and in vivo preclinical studies and the significant number of clinical trials currently enrolling worldwide, only a few data of AML patients treated with CAR T cells have been so far reported. The first published clinical trial employed a second generation CAR targeting the Lewis $Y$ antigen, an oligosaccharide overexpressed by some epithelial and hematological malignancies: signs of clinical activity and good tolerability were shown in the 4 treated patients, but responses were shortlived and CAR T cells persistence was limited (82). CD33 is an obvious target in AML, due to its very frequent expression on leukemic blasts, and several efforts are ongoing to increase anti-leukemia efficacy of CD33-directed constructs, including the optimization of co-stimulatory molecules (83). So far Chinese investigators reported only on one heavily pretreated patient who experienced a short-lasting partial response and moderate toxicity after CD33-CAR T cell treatment (84). Despite the disappointing results obtained with the adoptive transfer of $\mathrm{T}$ cells transiently modified by mRNA electroporation to 
express a CD123 specific CAR (70), preliminary clinical data on lentivirally transduced CD123-CARs are promising. One case report from China showed some clinical activity (85) and more recently the City of Hope group reported encouraging results on 6 AML patients, 3 of whom experienced a clinical meaningful response and, interestingly, no significant myelosuppression after anti-CD123 CAR T cell infusion. One patient with refractory blastic plasomocytoid dendritic cell neoplasm responded as well, obtaining a CR. CRS was observed, but it was manageable and always of grade 1 or 2 (86). Preclinical results of this construct were also reported in high risk MDS (87).

Universal allogeneic CAR T cells are of particular interest in AML, giving the increased manufacturing problems often faced with autologous CARs in this disease (88). Unfortunately, a phase I study of UCAR123 (i.e. allogenic anti-CD123 CART T cells) was temporarily halted due to unacceptable toxicity in the first two patients treated, including one fatal case, and data on further development of this construct are awaited (68). NKG2D-expressing CAR T cells (89) were tested in a phase I trial including 6 patients with MDS or AML, but poor CAR T cell persistence, no CRS and very limited clinical activity were shown (56). However, a relapsed AML patient enrolled in a trial testing multiple infusions of NKG2D-bearing CAR T cells obtained marrow leukemia free status at day 28 post infusion and was later successfully allografted (90). Recently, preliminary results of a compound CAR simultaneously targeting two different AML antigens, CLL1 and CD33, have been reported. After demonstrating significant activity of the construct in vitro and in a mouse model, and after proving the efficacy of alemtuzumab as safety switch, Liu and colleagues presented the results of the first patient treated, who achieved a minimal residual disease (MRD)-negative CR and could be successfully bridged to alloHSCT (91). Other AML targets have been studied in preclinical models with encouraging results, including folate receptor ß (92), CD7 (93), CD44v6 (54), CD38 (94), CLL1 (95), FLT3 (96), and LILRB4 (97), but CAR T cells directed toward these antigens have not entered clinical development or are tested in early trials whose results are not available yet.

\subsection{CAR T cells for solid tumors}

The development of CAR T cells in solid tumors has yielded limited results, since unique challenges come in addition to those faced in hematological malignancies (98) (Table 2). Likewise in AML, important safety concerns derive from the lack of highly specific target antigens, and severe and sometimes fatal toxicities due to on-target off-tumor effects on normal tissues occurred in some trials (99-102). Besides, the tumor microenvironment represents a unique obstacle which significantly limits CAR T cells efficacy in solid cancers, due to the presence of environmental barriers (e.g. extracellular matrix), chronic inflammation and the presence of immunosuppressive molecules and immune cells. Furthermore, high tumor heterogeneity can facilitate antigen escape and in vivo CAR T cells expansion is significantly less pronounced than in patients with hematologic malignancies $(103,104)$. In order to prevent potentially lethal toxicities, safety switch strategies are being tested (98) and the University of 
Pennsylvania group demonstrated the feasibility, although with limited efficacy, of administering mRNA electroporated mesothelin-specific CAR T cells in pancreatic adenocarcinoma patients (105). Other groups are exploring the possibility of local delivery, to enhance tumor killing and to reduce toxicity. Indeed, it has been shown that regional administration of anti-AFP or anti-CEA CAR T cells was equally effective or even superior to a systemic administration in xenograft models of peritoneal carcinomatosis $(106,107)$, and the delivery of CAR T cells through percutaneous hepatic artery infusions has shown to be safe and clinically active in patients with CEA-expressing liver metastases (108). A different approach to favor the localization into the tumor site consists in the administration of CAR T cells overexpressing tumor-specific chemokine receptors enhancing their capacity of reaching the tumor tissues (109).

In order to overcome antigen escape risk and inter-patient variability, CARs co-targeting two or even three antigens are being developed in several solid malignancies, including breast, pancreatic and brain tumors (110-113). Conversely, other investigators are testing dual constructs requiring both targets to be expressed on tumor cells in order to exert their cytotoxic activity (114) and inhibitory CARs able to redirect $\mathrm{T}$ cells activity from healthy tissues (115), with the aim of increasing CAR specificity and of preventing off-tumor side effects. Furthermore, many efforts are being made to optimize co-stimulatory molecules and to improve the structure of CARs (116), and new constructs able to locally deliver immune-modulating cytokines (117-120), bearing modified cytokine receptors (121) or targeting tumor matrix components $(122,123)$ are being developed to overcome environmental barriers. Some groups are also exploring the possibility of combing CAR T cells with oncolitic viruses (124) or with checkpoint inhibitors (125-127). Indeed, targeting the PD-1/PD-L1 axis is of particular interest for CAR-T cells development in solid tumors (128), and investigators are testing constructs which are able to deliver anti-PD-1 molecules $(129,130)$ and strategies of cell-intrinsic PD-1 inhibition and inactivation (126, 131, 132), with the aim of improving the efficacy of CAR T cells also reducing the systemic side effects of checkpoint inhibitors. Despite these challenges, basic and clinical research on CAR T cells in solid malignancies is constantly expanding, with more and more clinical trials opening worldwide (133) and many new data being presented. In sarcoma, anti HER2-CAR T cells showed a reassuring safety profile (134) and led to CR in one case (135) while anti-GD2 constructs demonstrated significant clinical activity in 5 out of 11 patients with active neuroblastoma, including 3 CR (136). Signs of activity were also shown in recent studies involving epithelial tumors (137-140). The concept of the central nervous system (CNS) as an immune privileged site has been overturned in recent years, since $\mathrm{T}$ cells can penetrate the blood-brain barrier and infiltrate the brain in a diffuse manner (141); as a matter of fact, one of the most promising field of CAR T cells development in solid malignancies are CNS tumors. In glioblastoma patients, the University of Pennsylvania group showed that EGFRvIII-directed CAR T cells effectively trafficked to regions of active tumor after systemic infusion (142) and Ahmed and colleagues reported clinically significant activity of HER2-specific CAR T cells in 8 out of 17 cases, including one PR and 7 persistent SD (143). Besides, local delivery showed encouraging results in this 
setting: in xenograft models, investigators demonstrated robust antitumor efficacy of anti-HER2 CAR $\mathrm{T}$ cells against medulloblastoma (144) and brain metastases of breast cancer (145) and anti-GD2 constructs were effective against midline gliomas (146). In addition, Brown and colleagues reported that IL-13R $\alpha 2-$ directed CAR $\mathrm{T}$ cells delivered via an implanted reservoir/catheter system exert a significant clinical activity in glioblastoma patients (147), including one CR (148).

\section{CAR-T cells related toxicities}

The two most relevant toxicities resulting from CAR $\mathrm{T}$ cell adoptive therapy are CRS and neurotoxicity. Both are potentially life-threatening conditions and their prompt recognition and safe management are essential. Recent observations in pre-clinical models are revealing some aspects of their obscure pathophysiology and new potential pathways that could be targetable.

\subsection{Cytokine release syndrome}

CRS is an acute inflammatory process that commonly occurs within the first days after CAR-T cell infusion. Closely related to the macrophage activation syndrome, it is characterized by non-specific constitutional symptoms with transient elevations of serum cytokines and other biomarkers. The delayed onset of clinical symptoms suggests an on-target, antigen-driven T-cell activation process. Mild CRS is a self-limiting clinical syndrome of low-grade fever, arthralgias and myalgias and is usually managed with minimal intervention. However, in a small number of patients it can progress to a dramatic syndrome of multi-organ dysfunction, requiring aggressive intervention and intensive life-support. Severe CRS is characterized by the development of a capillary leak syndrome with third spacing and hypotension, insufficient renal blood flow and pulmonary edema leading to hypoxia. Neurological symptoms may also occur during CRS though they generally do not follow the same time course as systemic CRS symptoms.

Though the pivotal role played by IL-6 in severe CRS is well known $(9,14)$, new intriguing observations correlate severe CRS with the host macrophage/monocyte system rather than the CAR-T cells induced cytokine milieu (149). This observation may reveal a novel scenario where the cross-talk between CAR T cells and host myeloid cells is essential for the recruitment of macrophages which, in turn, are responsible for the release of IL-6. Furthermore, the demonstration of the involvement of inducible nitric oxide synthase (iNOS) in CRS patho-physiology recognizes a role for IL-1, a strong iNOS inducer. In a mouse model, the administration of an IL-1 receptor antagonist prevented severe CRS while sparing anti-tumor efficacy (150).

Severe CRS treatment is based upon direct cytokine inhibition, corticosteroids and intensive life support. The IL-6 receptor antagonist tocilizumab has often been used and has resulted in rapid improvement of clinical symptoms without affective potential anti-tumor activity $(9,14,151)$. The use 
of tocilizumab was approved by the Food and Drugs Administration in August 2017. A currently ongoing clinical trial (NCT02906371) may contribute to establish the role of tocilizumab as prophylaxis of CRS in anti-CD19 CAR-T cells recipients. Corticosteroids have also been used as first-line treatment for severe CRS due to their well-known ability to blunt activated T-cells. However, given their potential risk of compromising CAR-T cells efficacy in vivo, their use is commonly limited to life-threatening CRS unresponsive to cytokine inhibition. Intensive care treatment may be required in case of refractory severe CRS with unstable blood pressure and/or ventilator-requiring hypoxia.

\subsection{Neurotoxicity}

CAR T-related neurologic adverse events include a wide spectrum of clinical symptoms that may develop with or without CRS. They are generally of mild-moderate intensity and reversible while only a minority of patients require specific treatment. Reported incidence ranges from $7 \%$ to $63 \%$ (15, $23,24,152)$.

The initial hypothesis of a brain-located CD19 acting as a powerful stimulus for an antigendriven CAR-T infiltration appeared not consistent. The recent development of a pre-clinical model of neurotoxicity through the transfer of autologous CD20-specific CAR T cells showed the association of neurotoxicity with pro-inflammatory cytokines in the cerebrospinal fluid (CSF) determined by a CAR $\mathrm{T}$ cell mediated meningeal inflammation (153). It was demonstrated that CAR T cells accumulate in CSF and brain parenchyma along with measurable CSF levels of multiple molecules such as IL-6, IL2, granulocyte-macrophage colony stimulating factor, and vascular endothelial growth factor. Disruption of central nervous system vascular integrity and disregulation of the platelet-von Willebrand factor axis along with high serum levels of endothelial activation biomarkers appear to play a major role during acute neurologic toxicity. The blood-brain barrier (BBB) of patients with acute neurotoxicity does not prevent massive cytokine penetration into CSF, that, in turn, induces brain vascular pericyte stress and secretion of cytokines further increasing BBB permeability in a cyclic process (154). Common neurologic symptoms include delirium, confusion, disorientation, headache, decreased level of consciousness, hallucinations and tremor, while cranial nerve damage, seizures and focal deficits have been infrequently observed. The occurrence of fatal cerebral edema has also been reported in the Kite Pharma trial and by Gust et al. $(154,155)$. Heavy disease burden, fludarabine-based preparative regimens and higher infused CAR-T cell doses have been associated with higher incidence of neurologic events. Higher serum levels of IL-6 and of monocyte chemo-attractant protein-1 within the first 36 hours after infusion appear to predict a higher risk of developing grade $\geq 4$ neurotoxicity (27). Most patients with severe neurotoxic events had previously been diagnosed with grade $\geq 2$ CRS but the physiopathologic relationship between the two morbid processes is currently unknown.

Patients who develop at least grade 2 neurologic toxicity after CAR T infusion should be managed by the neurology consult service. Brain magnetic resonance, electroencephalogram and 
examination of CSF could help to rule out other causes. Events of mild intensity are almost universally self-limited and do not need intervention. Severe neurotoxicity is treated with systemic corticosteroids with dexamethasone being the first choice given its excellent BBB penetration, and, in absence of prompt response, with tocilizumab although clear evidence of its efficacy is lacking. Given the inability of tocilizumab to cross the BBB, it was also suggested that it may increase IL-6 levels in CSF and worsen neurotoxicity. Thus the IL-6 antagonist siltuximab may be a valid alternative (156). A recent published observation showed that in a mouse model of CAR T-induced neurotoxicity, the use of IL-1 receptor antagonist anakinra abolished neurologic symptoms, whereas tocilizumab failed to treat them (150).

\section{Alternative sources and off-the-shelf carriers for CARs}

Despite stunning clinical results, autologous CAR T cells present some issues. First, advanced stage disease and previous multiple chemotherapies may affect $\mathrm{T}$ cell collections, both in quantity and quality. Second, patients are at risk of disease progression from the time of $\mathrm{T}$ cell harvest to the complete manufacturing process and shipment of the final autologous CAR-T products for patient infusion. Moreover, single manufacturing generates a product dedicated to a single patient resulting in significantly high costs. The high costs associated with de-centralized manufacturing place a burden on health care systems and restrict broad patient access to these novel therapies. Thus, the promising clinical results of engineered $\mathrm{T}$ cell therapies will be further amplified and broadened if potent and histocompatible $\mathrm{T}$ cells become readily available off-the-shelf. Major barriers to overcome are the risks of graft-versus-host disease (GVHD), caused by the reaction of manipulated donor cells against recipient tissues, and cell rejection, due to the recipient immune system acting against the infused donor cells. Herein, we report the preliminary clinical experiences on the use of other than autologous CAR T cells in hematological malignancies.

\subsection{Post-allogeneic stem cell transplant CAR T cells}

Disease relapse post allo-HSCT is at least theoretically the easiest setting for allogeneic donor CAR T cells. Unmanipulated donor lymphocyte infusion (DLI) is commonly used to treat patients with disease recurrence after allo-HSCT (157-159) though the risks of GVHD and lack of disease response remain an issue. The use of engineered donor-derived $\mathrm{T}$ cells to enhance graft-versus-leukemia effects and to limit the risk of GVHD is fascinating.

Most trials evaluated donor-derived CAR T cells against the B-cell antigen CD19 as target antigen. T cells were harvested from donors (160-163) or from engrafted recipients after allo-HSCT. In the latter case, all studies reported low rate of GVHD as CAR T cells were generated from tolerized cells $(14,27,151,164,165)$. Life-threatening viral infections with pathogens such as Epstein-Barr virus, 
cytomegalovirus, and adenoviruses after alloHSCT can be treated without toxicity (including GVHD) by infusing ex vivo-expanded, donor-derived, virus-specific cytotoxic T cells (VST) (166-169), which are also capable of persisting several years after infusion (170). Donor-derived VST genetically modified to express a CD19-specific CAR (CD19.CAR-VST) have therefore been investigated in patients with B-cell malignancies who have either disease relapse or are at high risk of disease relapse after alloHSCT with the hypothesis that CAR-VSTs would be activated by endogenous viral antigens, increasing their expansion and persistence irrespective of the presence of CD19-expressing normal or malignant B cells. Eight patients received CD19.CAR-VST 3 months to 13 years after alloHSCT. There were no infusion-related toxicities. Objective antitumor activity was evident in 2 of 6 patients with relapsed disease during the period of CD19.CAR-VST persistence, whereas 2 patients who received cells while in remission remain disease free. Of note, in 2 of 3 patients with viral reactivation, donor CD19.CAR-VSTs expanded concomitantly with VSTs (160). Twenty patients with hematological malignancy that persisted after alloHSCT and standard DLI received infusion of T cells, obtained from each patient's alloHSCT donor, genetically modified to express a CAR targeting CD19. Eight of 20 responded (6 CR and $2 \mathrm{PR}$ ). The response rate was highest for ALL, with 4/5 patients obtaining MRDnegative remission. Responses also occurred in CLL and NHL. The longest ongoing CR was more than 30 months in a patient with CLL. No new-onset acute GVHD after CAR-T infusion developed. Toxicities included fever, tachycardia, and hypotension. Peak blood CAR-T levels were higher in patients who obtained remissions than in those who did not $(162,171)$.

\subsection{Off-the-shelf allogeneic CAR T cells}

As stated above, the promising clinical results of engineered $\mathrm{T}$ cell therapy could be further amplified and broadened if potent and histocompatible $\mathrm{T}$ cells were readily available, instead of being collected and manufactured on demand. T cells can be easily harvested from healthy donor, but their use is compromised by the high allo-reactive potential. TCR are naturally prone to react against nonautologous tissues, recognizing either allogeneic HLA molecules or other polymorphic gene products (minor antigens) (172). Recent advances in gene editing technology allow the manufacture of CAR-T cells from healthy donor leukapheresis where quantity and quality of $\mathrm{T}$ cells can be pre-selected. However, the use of these CAR $\mathrm{T}$ cells requires gene editing technology to prevent expression of endogenous TCR in order to minimize the potential to cause GVHD in non-HLA matched recipients. TCR is a heterodimer and both $\alpha$ and $\beta$ chains need to be present for it to be expressed. A single gene codes for the $\alpha$ chain (TRAC), whereas there are 2 genes coding for the $\beta$ chain, and TRAC loci knocked out using nucleases is the choice strategy for removing TCR expression. Initially, procedures in two steps were used: the CAR was introduced with a viral vector and the TRAC loci disrupted using a nuclease. Zinc finger nucleases (ZFN) (173), transcription activator-like effector nucleases (TALEN) and megaTAL nucleases (174-176), and CRISPR/Cas9 systems (177) have all been applied to modify 
T cells (178-180). As previously mentioned, Qasim et al. reported the clinical use of UCART19s, generated by lentiviral transduction of donor cells and simultaneous TALEN-mediated gene editing of TRAC and CD52 gene loci (29). More recently, a one step only procedure was introduced: the CARencoding DNA was directly inserted into the TRAC locus using CRISPR/Cas9 technology together with an adeno-associated virus (AAV) vector repair matrix, simultaneously generating a TCR-negative CARpositive $\mathrm{T}$ cell (181). These cells were shown to be more potent than conventional lentivirally transduced CAR T cells because of a more physiological, TCR-like regulation of CAR expression. Although TCRnegative off-the-shelf CAR T cells are able to reduce the risk of GVHD, they may still be subjected to killing by the patient's own T cells that recognize non-self HLA if there is mismatch, causing rejection and subsequently leading to short-lasting responses. To solve this issue, it has been proposed to eliminate the HLA molecules from CAR T cells using gene-editing technologies like ZFN (182).

Another way to protect allogeneic CAR T cells from rejection included the knockout of the $\beta 2$ microglobulin gene combined with TCR knockout. In the absence of $\beta 2$-microglobulin ( $\beta$ chain), class I HLA molecules do not form stable heterodimer on the cell surface (183). However, while the absence of HLA-I on the surface of CAR T cells significantly reduces rejection through HLA-mismatched CD8 T cells (class-I restricted), it can result in increased destruction by recipients' NK cells, due to "missing self" recognition. To prevent activation of recipient's NK cells through this mechanism, different way have been tested, such as the enforced expression of non-classical HLA molecules (e.g. HLA-E and HLA-G) $(182,184)$, and the overexpression of Siglec-7 and -9 ligands (185). Furthermore, the use of HLA homozygous donors to generate a bank of universal CAR T products may represent an additional strategy to avoid rejection. It was calculated that with limited numbers of donors homozygous for HLA$\mathrm{A} / \mathrm{B} / \mathrm{DRB} 1$, it would be possible to generate compatible products to cover the majority of the population (186).

\subsection{Alternative off-the-shelf CAR carriers}

Additional immune cells are on studies as potential off-the-shelf CAR carriers, although the safety, efficacy and persistence in the clinical setting require more investigations. Natural killer (NK) cells belong to the lymphoid branch of the immune system and account for up to $6 \%$ of circulating lymphocytes. NK cells do not express rearranged receptors and can be easily transferred across HLA barriers without causing GVHD, thus they became attractive as allogeneic effector cells $(187,188)$. At least three different sources of NK cells are currently available: NK cell line (189), peripheral blood NK cells (189), and induced pluripotent stem cells (iPSC) NK cells (190). In clinical studies of postalloHSCT, NK cell infusion demonstrated the safety of using such an approach in an off-the-shelf fashion (191). CAR expression in NK cells could increase their specificity and enhanced their anti-tumor activity. NK cells have been utilized to evaluate several different antigens as CAR target. In pre-clinical 
studies, potent antitumor activity has been demonstrated using CAR NK cells generated from NK cell lines as well as NK cells derived from patients (192).

Gammadelta $\mathrm{T}$ cells ( $\gamma \delta \mathrm{T}$ cells) are less prone to alloreactivity compare to other $\mathrm{T}$ cells. Immunotherapy with $\gamma \delta \mathrm{T}$ cells requires their activation and expansion as they represent only a small amount of circulating T cells. Aminobisphosphonates are the most efficient reagents to grow $\gamma \delta \mathrm{T}$ cells ex vivo. Afterward, the same technique have been transitioned to the clinic for investigational treatments of cancer and HIV $(193,194)$. In the alloHSCT setting $\gamma \delta \mathrm{T}$ cells exert anti-tumor activities and contribute to host defense against different pathogens, whereas their role in GVHD management remains unclear $(195,196)$. For this reason, $\gamma \delta \mathrm{T}$ cells have been evaluated in the setting of $\mathrm{T}$ cell-depleted alloHSCT $(195,196)$. Given their inherent potential for antitumor effects and their apparent lack of alloreactivity the combination of $\gamma \delta$ T cells with CAR is appealing (197-199), however, although initial clinical trial with CAR $\gamma \delta \mathrm{T}$ cells are ongoing, far more data are needed to assess if preclinical findings translate into powerfull and pesistent anti-tumor activity with acceptable toxicity.

NKT cells constitute a relatively uncommon circulating immune cell population $(0.1-0.5 \%$ of $\mathrm{T}$ cells) that co-expresses $\alpha \beta T C R$ and NK cell markers. In mice models, was found an inverse correlation of recovery of NKT cells and GVHD after alloHSCT while preserving a graft-versus-tumor response (200). NKT cells can also be expanded in vitro and can be genetically modified to express CAR (201, 202). Thanks to limited TCR alloreactivity and emerging technology to obtain large numbers, NKT cells represent another attractive source to generate off-the-shelf CAR+ immune cells.

\section{Conclusion and Perspectives}

The ultimate goal of adoptive cell therapies is to create a personalized cellular product directed against the malignancy with minimal side effects. CAR-engineered $\mathrm{T}$ cells represent an important breakthrough in personalized medicine. Future directions to improve efficacy and safety include potential combinations with immunomodulatory drugs, checkpoint inhibitors, or other CAR T cells engineered to contain suicide genes or switches (i.e. iCasp9) which are currently being evaluated in preclinical and clinical studies. In summary, CAR T cells represent a personalized immunotherapeutic approach that has developed very rapidly in recent years. Great successes have been observed in lymphoproliferative disorders. However, further optimization of this promising cell therapies is still needed to enhance anti-tumor effects and reduce associated toxicities. As of November 2018, more than 100 clinical trials are currently recruiting. Moreover, advances in the field of CAR T cell biology over the coming years in terms of safety, reliability and efficacy against non-hematopoietic cancers will ultimately determine the role of adoptive $\mathrm{T}$ cell therapy in the fight against cancer.

\section{Acknowledgement}


Supported in part by Fondi di Ricerca Locale, Università degli Studi di Torino, Torino, Italy; Fondazione Neoplasie del sangue (FO.NE. SA), Torino, Italy; Fondazione Cariplo (Grant per la Ricerca Biomedica 2015/0603 to BB). C.V. received the 2019 Fondazione Pezcoller-Ferruccio ed Elena Bernardi fellowship.

\section{References}

1. C. H. June, R. S. O'Connor, O. U. Kawalekar, S. Ghassemi and M. C. Milone: CAR T cell immunotherapy for human cancer. Science, 359(6382), 1361-1365 (2018) doi:10.1126/science.aar6711 2. M. Sadelain, I. Riviere and S. Riddell: Therapeutic T cell engineering. Nature, 545(7655), 423431 (2017) doi:10.1038/nature22395

3. J. Scholler, T. L. Brady, G. Binder-Scholl, W. T. Hwang, G. Plesa, K. M. Hege, A. N. Vogel, M. Kalos, J. L. Riley, S. G. Deeks, R. T. Mitsuyasu, W. B. Bernstein, N. E. Aronson, B. L. Levine, F. D. Bushman and C. H. June: Decade-long safety and function of retroviral-modified chimeric antigen receptor T cells. Sci Transl Med, 4(132), 132ra53 (2012) doi:10.1126/scitranslmed.3003761

4. F. Chu, J. Cao and S. S. Neelalpu: Versatile CAR T-cells for cancer immunotherapy. Contemp Oncol (Pozn), 22(1A), 73-80 (2018) doi:10.5114/wo.2018.73892

5. G. Gross, T. Waks and Z. Eshhar: Expression of immunoglobulin-T-cell receptor chimeric molecules as functional receptors with antibody-type specificity. Proc Natl Acad Sci U S A, 86(24), 10024-8 (1989)

6. Y. Kuwana, Y. Asakura, N. Utsunomiya, M. Nakanishi, Y. Arata, S. Itoh, F. Nagase and Y. Kurosawa: Expression of chimeric receptor composed of immunoglobulin-derived V regions and T-cell receptor-derived C regions. Biochem Biophys Res Commun, 149(3), 960-8 (1987)

7. R. J. Brentjens, I. Riviere, J. H. Park, M. L. Davila, X. Wang, J. Stefanski, C. Taylor, R. Yeh, S. Bartido, O. Borquez-Ojeda, M. Olszewska, Y. Bernal, H. Pegram, M. Przybylowski, D. Hollyman, Y. Usachenko, D. Pirraglia, J. Hosey, E. Santos, E. Halton, P. Maslak, D. Scheinberg, J. Jurcic, M. Heaney, G. Heller, M. Frattini and M. Sadelain: Safety and persistence of adoptively transferred autologous CD19-targeted T cells in patients with relapsed or chemotherapy refractory B-cell leukemias. Blood, 118(18), 4817-28 (2011) doi:10.1182/blood-2011-04-348540

8. D. L. Porter, B. L. Levine, M. Kalos, A. Bagg and C. H. June: Chimeric antigen receptormodified $\mathrm{T}$ cells in chronic lymphoid leukemia. $N$ Engl $J$ Med, 365(8), 725-33 (2011) doi:10.1056/NEJMoa1103849

9. $\quad$ S. A. Grupp, M. Kalos, D. Barrett, R. Aplenc, D. L. Porter, S. R. Rheingold, D. T. Teachey, A. Chew, B. Hauck, J. F. Wright, M. C. Milone, B. L. Levine and C. H. June: Chimeric antigen receptormodified T cells for acute lymphoid leukemia. N Engl J Med, 368(16), 1509-1518 (2013) doi:10.1056/NEJMoa1215134

10. R. J. Brentjens, J. B. Latouche, E. Santos, F. Marti, M. C. Gong, C. Lyddane, P. D. King, S. Larson, M. Weiss, I. Riviere and M. Sadelain: Eradication of systemic B-cell tumors by genetically targeted human T lymphocytes co-stimulated by CD80 and interleukin-15. Nat Med, 9(3), 279-86 (2003) doi: $10.1038 / \mathrm{nm} 827$

11. C. Imai, K. Mihara, M. Andreansky, I. C. Nicholson, C. H. Pui, T. L. Geiger and D. Campana: Chimeric receptors with 4-1BB signaling capacity provoke potent cytotoxicity against acute lymphoblastic leukemia. Leukemia, 18(4), 676-84 (2004) doi:10.1038/sj.leu.2403302

12. J. Maher, R. J. Brentjens, G. Gunset, I. Riviere and M. Sadelain: Human T-lymphocyte cytotoxicity and proliferation directed by a single chimeric TCRzeta /CD28 receptor. Nat Biotechnol, 20(1), 70-5 (2002) doi:10.1038/nbt0102-70

13. R. J. Brentjens, M. L. Davila, I. Riviere, J. Park, X. Wang, L. G. Cowell, S. Bartido, J. Stefanski, C. Taylor, M. Olszewska, O. Borquez-Ojeda, J. Qu, T. Wasielewska, Q. He, Y. Bernal, I. V. Rijo, C. Hedvat, R. Kobos, K. Curran, P. Steinherz, J. Jurcic, T. Rosenblat, P. Maslak, M. Frattini and M. Sadelain: CD19-targeted $\mathrm{T}$ cells rapidly induce molecular remissions in adults with chemotherapy- 
refractory acute lymphoblastic leukemia. Sci Transl Med, 5(177), 177ra38 (2013) doi:10.1126/scitranslmed.3005930

14. S. L. Maude, N. Frey, P. A. Shaw, R. Aplenc, D. M. Barrett, N. J. Bunin, A. Chew, V. E. Gonzalez, Z. Zheng, S. F. Lacey, Y. D. Mahnke, J. J. Melenhorst, S. R. Rheingold, A. Shen, D. T. Teachey, B. L. Levine, C. H. June, D. L. Porter and S. A. Grupp: Chimeric antigen receptor T cells for sustained remissions in leukemia. $N$ Engl $J$ Med, 371(16), 1507-17 (2014) doi:10.1056/NEJMoa1407222

15. S. L. Maude, T. W. Laetsch, J. Buechner, S. Rives, M. Boyer, H. Bittencourt, P. Bader, M. R. Verneris, H. E. Stefanski, G. D. Myers, M. Qayed, B. De Moerloose, H. Hiramatsu, K. Schlis, K. L. Davis, P. L. Martin, E. R. Nemecek, G. A. Yanik, C. Peters, A. Baruchel, N. Boissel, F. Mechinaud, A. Balduzzi, J. Krueger, C. H. June, B. L. Levine, P. Wood, T. Taran, M. Leung, K. T. Mueller, Y. Zhang, K. Sen, D. Lebwohl, M. A. Pulsipher and S. A. Grupp: Tisagenlecleucel in Children and Young Adults with B-Cell Lymphoblastic Leukemia. $N$ Engl J Med, 378(5), 439-448 (2018) doi:10.1056/NEJMoa1709866

16. S. J. Schuster, J. Svoboda, E. A. Chong, S. D. Nasta, A. R. Mato, O. Anak, J. L. Brogdon, I. Pruteanu-Malinici, V. Bhoj, D. Landsburg, M. Wasik, B. L. Levine, S. F. Lacey, J. J. Melenhorst, D. L. Porter and C. H. June: Chimeric Antigen Receptor T Cells in Refractory B-Cell Lymphomas. N Engl J Med, 377(26), 2545-2554 (2017) doi:10.1056/NEJMoa1708566

17. S. J. Schuster, M. R. Bishop, C. S. Tam, E. K. Waller, P. Borchmann, J. P. McGuirk, U. Jaeger, S. Jaglowski, C. Andreadis, J. R. Westin, I. Fleury, V. Bachanova, S. R. Foley, P. J. Ho, S. Mielke, J. M. Magenau, H. Holte, K. Van Besien, M. J. Kersten, T. Teshima, K. Tobinai, P. Corradini, O. Anak, L. Bubuteishvili Pacaud, C. del Corral, R. Awasthi, F. Tai, G. Salles and R. T. Maziarz: Primary Analysis of Juliet: A Global, Pivotal, Phase 2 Trial of CTL019 in Adult Patients with Relapsed or Refractory Diffuse Large B-Cell Lymphoma. Blood, 130(Suppl 1), 577-577 (2017)

18. D. L. himeric antigen receptor $\mathrm{T}$ cells persist and induce sustained remissions in relapsed refractory chronic lymphocytic leukemiaPorter, W. T. Hwang, N. V. Frey, S. F. Lacey, P. A. Shaw, A. W. Loren, A. Bagg, K. T. Marcucci, A. Shen, V. Gonzalez, D. Ambrose, S. A. Grupp, A. Chew, Z. Zheng, M. C. Milone, B. L. Levine, J. J. Melenhorst and C. H. June: Chimeric antigen receptor T cells persist and induce sustained remissions in relapsed refractory chronic lymphocytic leukemia. Sci Transl Med, 7(303), 303ra139 (2015) doi:10.1126/scitranslmed.aac5415

19. A. L. Garfall, E. A. Stadtmauer, W. T. Hwang, S. F. Lacey, J. J. Melenhorst, M. Krevvata, M. P. Carroll, W. H. Matsui, Q. Wang, M. V. Dhodapkar, K. Dhodapkar, R. Das, D. T. Vogl, B. M. Weiss, A. D. Cohen, P. A. Mangan, E. C. Ayers, S. Nunez-Cruz, I. Kulikovskaya, M. M. Davis, A. Lamontagne, K. Dengel, N. D. Kerr, R. M. Young, D. L. Siegel, B. L. Levine, M. C. Milone, M. V. Maus and C. H. June: Anti-CD19 CAR T cells with high-dose melphalan and autologous stem cell transplantation for refractory multiple myeloma. JCI Insight, 3(8) (2018) doi:10.1172/jci.insight.120505

20. J. N. Kochenderfer, M. E. Dudley, S. H. Kassim, R. P. Somerville, R. O. Carpenter, M. StetlerStevenson, J. C. Yang, G. Q. Phan, M. S. Hughes, R. M. Sherry, M. Raffeld, S. Feldman, L. Lu, Y. F. Li, L. T. Ngo, A. Goy, T. Feldman, D. E. Spaner, M. L. Wang, C. C. Chen, S. M. Kranick, A. Nath, D. A. Nathan, K. E. Morton, M. A. Toomey and S. A. Rosenberg: Chemotherapy-refractory diffuse large B-cell lymphoma and indolent B-cell malignancies can be effectively treated with autologous $\mathrm{T}$ cells expressing an anti-CD19 chimeric antigen receptor. J Clin Oncol, 33(6), 540-9 (2015) doi:10.1200/jco.2014.56.2025

21. J. N. Kochenderfer, R. P. T. Somerville, T. Lu, J. C. Yang, R. M. Sherry, S. A. Feldman, L. McIntyre, A. Bot, J. Rossi, N. Lam and S. A. Rosenberg: Long-Duration Complete Remissions of Diffuse Large B Cell Lymphoma after Anti-CD19 Chimeric Antigen Receptor T Cell Therapy. Mol Ther, 25(10), 2245-2253 (2017) doi:10.1016/j.ymthe.2017.07.004

22. F. L. Locke, S. S. Neelapu, N. L. Bartlett, T. Siddiqi, J. C. Chavez, C. M. Hosing, A. Ghobadi, L. E. Budde, A. Bot, J. M. Rossi, Y. Jiang, A. X. Xue, M. Elias, J. Aycock, J. Wiezorek and W. Y. Go: Phase 1 Results of ZUMA-1: A Multicenter Study of KTE-C19 Anti-CD19 CAR T Cell Therapy in Refractory Aggressive Lymphoma. Mol Ther, 25(1), 285-295 (2017) doi:10.1016/j.ymthe.2016.10.020 23. S. S. Neelapu, F. L. Locke, N. L. Bartlett, L. J. Lekakis, D. B. Miklos, C. A. Jacobson, I. Braunschweig, O. O. Oluwole, T. Siddiqi, Y. Lin, J. M. Timmerman, P. J. Stiff, J. W. Friedberg, I. W. Flinn, A. Goy, B. T. Hill, M. R. Smith, A. Deol, U. Farooq, P. McSweeney, J. Munoz, I. Avivi, J. E. Castro, J. R. Westin, J. C. Chavez, A. Ghobadi, K. V. Komanduri, R. Levy, E. D. Jacobsen, T. E. Witzig, 
P. Reagan, A. Bot, J. Rossi, L. Navale, Y. Jiang, J. Aycock, M. Elias, D. Chang, J. Wiezorek and W. Y. Go: Axicabtagene Ciloleucel CAR T-Cell Therapy in Refractory Large B-Cell Lymphoma. $N$ Engl J Med, 377(26), 2531-2544 (2017) doi:10.1056/NEJMoa1707447

24. B. D. Shah, W. Stock, W. G. Wierda, O. Oluwole, H. Holmes, G. J. Schiller, M. S. Topp, M. J. Kersten, R. Houot, N. Boissel, M. Mojadidi, A. Xue, A. Mardiros, Y. Jiang, T. Shen, J. S. Aycock, S. Stout, J. S. Wiezorek and R. Jain: Phase 1 Results of ZUMA-3: KTE-C19, an Anti-CD19 Chimeric Antigen Receptor (CAR) $\mathrm{T}$ Cell Therapy, in Adult Patients with Relapsed/Refractory Acute Lymphoblastic Leukemia (R/R ALL). Blood, 130(Suppl 1), 888-888 (2017)

25. D. Sommermeyer, M. Hudecek, P. L. Kosasih, T. Gogishvili, D. G. Maloney, C. J. Turtle and S. R. Riddell: Chimeric antigen receptor-modified T cells derived from defined CD8+ and CD4+ subsets confer superior antitumor reactivity in vivo. Leukemia, 30(2), 492-500 (2016) doi:10.1038/leu.2015.247 26. C. J. Turtle, L. A. Hanafi, C. Berger, M. Hudecek, B. Pender, E. Robinson, R. Hawkins, C. Chaney, S. Cherian, X. Chen, L. Soma, B. Wood, D. Li, S. Heimfeld, S. R. Riddell and D. G. Maloney: Immunotherapy of non-Hodgkin's lymphoma with a defined ratio of CD8+ and CD4+ CD19-specific chimeric antigen receptor-modified T cells. Sci Transl Med, 8(355), 355ra116 (2016) doi:10.1126/scitranslmed.aaf8621

27. C. J. Turtle, L. A. Hanafi, C. Berger, T. A. Gooley, S. Cherian, M. Hudecek, D. Sommermeyer, K. Melville, B. Pender, T. M. Budiarto, E. Robinson, N. N. Steevens, C. Chaney, L. Soma, X. Chen, C. Yeung, B. Wood, D. Li, J. Cao, S. Heimfeld, M. C. Jensen, S. R. Riddell and D. G. Maloney: CD19 CAR-T cells of defined CD4+:CD8+ composition in adult B cell ALL patients. J Clin Invest, 126(6), 2123-38 (2016) doi:10.1172/jci85309

28. J. S. Abramson, M. L. Palomba, L. I. Gordon, M. A. Lunning, J. E. Arnason, M. Wang, A. Forero, D. G. Maloney, T. Albertson, J. Garcia, D. Li, B. Xie and T. Siddiqi: High Durable CR Rates in Relapsed/Refractory (R/R) Aggressive B-NHL Treated with the CD19-Directed CAR T Cell Product JCAR017 (TRANSCEND NHL 001): Defined Composition Allows for Dose-Finding and Definition of Pivotal Cohort. Blood, 130(Suppl 1), 581-581 (2017)

29. W. Qasim, H. Zhan, S. Samarasinghe, S. Adams, P. Amrolia, S. Stafford, K. Butler, C. Rivat, G. Wright, K. Somana, S. Ghorashian, D. Pinner, G. Ahsan, K. Gilmour, G. Lucchini, S. Inglott, W. Mifsud, R. Chiesa, K. S. Peggs, L. Chan, F. Farzeneh, A. J. Thrasher, A. Vora, M. Pule and P. Veys: Molecular remission of infant B-ALL after infusion of universal TALEN gene-edited CAR T cells. Sci Transl Med, 9(374) (2017) doi:10.1126/scitranslmed.aaj2013

30. W. Qasim, O. Ciocarlie, S. Adams, S. Inglott, C. Murphy, C. Rivat, G. Wright, G. Lucchini, J. Silva, K. Rao, A. Zinaï, F. Binlich, S. Dupouy, J. Pauly, S. Balandraud, F. Dubois, C. Konto, P. Patel, R. Chiesa, S. Samarasinghe, H. Hara, A. Boyle, J. Chu, D. Pinner, P. J. Amrolia, A. Vora, A. Rao, P. Ancliffe and P. Veys: Preliminary Results of UCART19, an Allogeneic Anti-CD19 CAR T-Cell Product in a First-in-Human Trial (PALL) in Pediatric Patients with CD19+ Relapsed/Refractory B-Cell Acute Lymphoblastic Leukemia. Blood, 130(Suppl 1), 1271-1271 (2017)

31. W. Yang, N. Agrawal, J. Patel, A. Edinger, E. Osei, D. Thut, J. Powers and H. Meyerson: Diminished expression of CD19 in B-cell lymphomas. Cytometry B Clin Cytom, 63(1), 28-35 (2005) doi:10.1002/cyto.b.20030

32. E. J. Orlando, X. Han, C. Tribouley, P. A. Wood, R. J. Leary, M. Riester, J. E. Levine, M. Qayed, S. A. Grupp, M. Boyer, B. De Moerloose, E. R. Nemecek, H. Bittencourt, H. Hiramatsu, J. Buechner, S. M. Davies, M. R. Verneris, K. Nguyen, J. L. Brogdon, H. Bitter, M. Morrissey, P. Pierog, S. Pantano, J. A. Engelman and W. Winckler: Genetic mechanisms of target antigen loss in CAR19 therapy of acute lymphoblastic leukemia. Nat Med, 24(10), 1504-1506 (2018) doi:10.1038/s41591-0180146-Z

33. B. G. Till, M. C. Jensen, J. Wang, E. Y. Chen, B. L. Wood, H. A. Greisman, X. Qian, S. E. James, A. Raubitschek, S. J. Forman, A. K. Gopal, J. M. Pagel, C. G. Lindgren, P. D. Greenberg, S. R. Riddell and O. W. Press: Adoptive immunotherapy for indolent non-Hodgkin lymphoma and mantle cell lymphoma using genetically modified autologous CD20-specific T cells. Blood, 112(6), 2261-71 (2008) doi:10.1182/blood-2007-12-128843

34. B. G. Till, M. C. Jensen, J. Wang, X. Qian, A. K. Gopal, D. G. Maloney, C. G. Lindgren, Y. Lin, J. M. Pagel, L. E. Budde, A. Raubitschek, S. J. Forman, P. D. Greenberg, S. R. Riddell and O. W. Press: CD20-specific adoptive immunotherapy for lymphoma using a chimeric antigen receptor with 
both CD28 and 4-1BB domains: pilot clinical trial results. Blood, 119(17), 3940-50 (2012) doi:10.1182/blood-2011-10-387969

35. T. J. Fry, N. N. Shah, R. J. Orentas, M. Stetler-Stevenson, C. M. Yuan, S. Ramakrishna, P. Wolters, S. Martin, C. Delbrook, B. Yates, H. Shalabi, T. J. Fountaine, J. F. Shern, R. G. Majzner, D. F. Stroncek, M. Sabatino, Y. Feng, D. S. Dimitrov, L. Zhang, S. Nguyen, H. Qin, B. Dropulic, D. W. Lee and C. L. Mackall: CD22-targeted CAR T cells induce remission in B-ALL that is naive or resistant to CD19-targeted CAR immunotherapy. Nat Med, 24(1), 20-28 (2018) doi:10.1038/nm.4441

36. C. A. Ramos, B. Savoldo, V. Torrano, B. Ballard, H. Zhang, O. Dakhova, E. Liu, G. Carrum, R. T. Kamble, A. P. Gee, Z. Mei, M. F. Wu, H. Liu, B. Grilley, C. M. Rooney, M. K. Brenner, H. E. Heslop and G. Dotti: Clinical responses with T lymphocytes targeting malignancy-associated kappa light chains. J Clin Invest, 126(7), 2588-96 (2016) doi:10.1172/jci86000

37. S. Baskar, K. Y. Kwong, T. Hofer, J. M. Levy, M. G. Kennedy, E. Lee, L. M. Staudt, W. H. Wilson, A. Wiestner and C. Rader: Unique cell surface expression of receptor tyrosine kinase ROR1 in human B-cell chronic lymphocytic leukemia. Clin Cancer Res, 14(2), 396-404 (2008) doi:10.1158/1078-0432.ccr-07-1823

38. A. H. Daneshmanesh, E. Mikaelsson, M. Jeddi-Tehrani, A. A. Bayat, R. Ghods, M. Ostadkarampour, M. Akhondi, S. Lagercrantz, C. Larsson, A. Osterborg, F. Shokri, H. Mellstedt and H. Rabbani: Ror1, a cell surface receptor tyrosine kinase is expressed in chronic lymphocytic leukemia and may serve as a putative target for therapy. Int J Cancer, 123(5), 1190-5 (2008) doi:10.1002/ijc.23587

39. M. Hudecek, T. M. Schmitt, S. Baskar, M. T. Lupo-Stanghellini, T. Nishida, T. N. Yamamoto, M. Bleakley, C. J. Turtle, W. C. Chang, H. A. Greisman, B. Wood, D. G. Maloney, M. C. Jensen, C. Rader and S. R. Riddell: The B-cell tumor-associated antigen ROR1 can be targeted with T cells modified to express a ROR1-specific chimeric antigen receptor. Blood, 116(22), 4532-41 (2010) doi:10.1182/blood-2010-05-283309

40. A. Gentile, L. Lazzari, S. Benvenuti, L. Trusolino and P. M. Comoglio: Ror1 is a pseudokinase that is crucial for Met-driven tumorigenesis. Cancer Res, 71(8), 3132-41 (2011) doi:10.1158/00085472.can-10-2662

41. M. Choi, G. F. Widhopf II, J. Yu, L. Chen, M. K. Hasan, L. Z. Rassenti, E. Pittman, K. Messer, C. Gutierrez, R. L. Kidwell, C. E. Prussak, J. E. Castro, C. Jamieson and T. J. Kipps: Durable and Specific Inhibition of ROR1 Signaling Associates with Prolonged Progression Free Survival in Patients with Chronic Lymphocytic Leukemia Treated with Cirmtuzumab. Blood, 130(Suppl 1), 829-829 (2017) 42. S. H. Gohil, S. R. Paredes-Moscosso, M. Harrasser, M. Vezzalini, A. Scarpa, E. Morris, A. M. Davidoff, C. Sorio, A. C. Nathwani and M. Della Peruta: An ROR1 bi-specific T-cell engager provides effective targeting and cytotoxicity against a range of solid tumors. Oncoimmunology, 6(7), e1326437 (2017) doi:10.1080/2162402x.2017.1326437

43. M. Hojjat-Farsangi, A. H. Daneshmanesh, A. S. Khan, J. Shetye, F. Mozaffari, P. Kharaziha, L. S. Rathje, P. Kokhaei, L. Hansson, J. Vagberg, S. Bystrom, E. Olsson, C. Lofberg, C. Norstrom, J. Schultz, M. Norin, T. Olin, A. Osterborg, H. Mellstedt and A. Moshfegh: First-in-class oral small molecule inhibitor of the tyrosine kinase ROR1 (KAN0439834) induced significant apoptosis of chronic lymphocytic leukemia cells. Leukemia, 32(10), 2291-2295 (2018) doi:10.1038/s41375-018-0113-1

44. C. Berger, D. Sommermeyer, M. Hudecek, M. Berger, A. Balakrishnan, P. J. Paszkiewicz, P. L. Kosasih, C. Rader and S. R. Riddell: Safety of targeting ROR1 in primates with chimeric antigen receptor-modified T cells. Cancer Immunol Res, 3(2), 206-16 (2015) doi:10.1158/2326-6066.cir-140163

45. F. Gay, M. Engelhardt, E. Terpos, R. Wasch, L. Giaccone, H. W. Auner, J. Caers, M. Gramatzki, N. van de Donk, S. Oliva, E. Zamagni, L. Garderet, C. Straka, R. Hajek, H. Ludwig, H. Einsele, M. Dimopoulos, M. Boccadoro, N. Kroger, M. Cavo, H. Goldschmidt, B. Bruno and P. Sonneveld: From transplant to novel cellular therapies in multiple myeloma: European Myeloma Network guidelines and future perspectives. Haematologica, 103(2), 197-211 (2018) doi:10.3324/haematol.2017.174573

46. F. Gay, M. D'Agostino, L. Giaccone, M. Genuardi, M. Festuccia, M. Boccadoro and B. Bruno: Immuno-oncologic Approaches: CAR-T Cells and Checkpoint Inhibitors. Clin Lymphoma Myeloma Leuk, 17(8), 471-478 (2017) doi:10.1016/j.clml.2017.06.014

47. E. Drent, R. W. Groen, W. A. Noort, M. Themeli, J. J. Lammerts van Bueren, P. W. Parren, J. Kuball, Z. Sebestyen, H. Yuan, J. de Bruijn, N. W. van de Donk, A. C. Martens, H. M. Lokhorst and T. 
Mutis: Pre-clinical evaluation of CD38 chimeric antigen receptor engineered T cells for the treatment of multiple myeloma. Haematologica, 101(5), 616-25 (2016) doi:10.3324/haematol.2015.137620

48. T. Gogishvili, S. Danhof, S. Prommersberger, J. Rydzek, M. Schreder, C. Brede, H. Einsele and M. Hudecek: SLAMF7-CAR T cells eliminate myeloma and confer selective fratricide of SLAMF7(+) normal lymphocytes. Blood, 130(26), 2838-2847 (2017) doi:10.1182/blood-2017-04-778423

49. J. N. Brudno, I. Maric, S. D. Hartman, J. J. Rose, M. Wang, N. Lam, M. Stetler-Stevenson, D. Salem, C. Yuan, S. Pavletic, J. A. Kanakry, S. A. Ali, L. Mikkilineni, S. A. Feldman, D. F. Stroncek, B. G. Hansen, J. Lawrence, R. Patel, F. Hakim, R. E. Gress and J. N. Kochenderfer: T Cells Genetically Modified to Express an Anti-B-Cell Maturation Antigen Chimeric Antigen Receptor Cause Remissions of Poor-Prognosis Relapsed Multiple Myeloma. J Clin Oncol, 36(22), 2267-2280 (2018) doi:10.1200/jco.2018.77.8084

50. A. D. Cohen, A. L. Garfall, E. A. Stadtmauer, S. F. Lacey, E. Lancaster, D. T. Vogl, B. M. Weiss, D. E. Ambrose, A. M. Nelson, F. Chen, G. Plesa, I. Kulikovskaya, V. Gonzalez, M. Gupta, R. M. Young, K. Dengel, L. O'keefe, S. Le, C. Richardson, R. E. Isaacs, J. J. Melenhorst, B. L. Levine, C. H. June and M. C. Milone: Safety and Efficacy of B-Cell Maturation Antigen (BCMA)-Specific Chimeric Antigen Receptor T Cells (CART-BCMA) with Cyclophosphamide Conditioning for Refractory Multiple Myeloma (MM). Blood, 130(Suppl 1), 505-505 (2017)

51. J. G. Berdeja, Y. Lin, N. Raje, N. Munshi, D. Siegel, M. Liedtke, S. Jagannath, M. V. Maus, A. Turka, L. P. Lam, K. Hege, R. A. Morgan, M. T. Quigley and J. N. Kochenderfer: Durable Clinical Responses in Heavily Pretreated Patients with Relapsed/Refractory Multiple Myeloma: Updated Results from a Multicenter Study of bb2121 Anti-Bcma CAR T Cell Therapy. Blood, 130(Suppl 1), 740-740 (2017)

52. K. M. Friedman, T. E. Garrett, J. W. Evans, H. M. Horton, H. J. Latimer, S. L. Seidel, C. J. Horvath and R. A. Morgan: Effective Targeting of Multiple B-Cell Maturation Antigen-Expressing Hematological Malignances by Anti-B-Cell Maturation Antigen Chimeric Antigen Receptor T Cells. Hum Gene Ther, 29(5), 585-601 (2018) doi:10.1089/hum.2018.001

53. F. Fan, W. Zhao, J. Liu, A. He, Y. Chen, X. Cao, N. Yang, B. Wang, P. Zhang, Y. Zhang, F. Wang, B. Lei, L. Gu, X. Wang, Q. Zhuang and W. Zhang: Durable remissions with BCMA-specific chimeric antigen receptor (CAR)-modified $\mathrm{T}$ cells in patients with refractory/relapsed multiple myeloma. Journal of Clinical Oncology, 35(18_suppl), LBA3001-LBA3001 (2017) doi:10.1200/JCO.2017.35.18_suppl.LBA3001

54. M. Casucci, B. Nicolis di Robilant, L. Falcone, B. Camisa, M. Norelli, P. Genovese, B. Gentner, F. Gullotta, M. Ponzoni, M. Bernardi, M. Marcatti, A. Saudemont, C. Bordignon, B. Savoldo, F. Ciceri, L. Naldini, G. Dotti, C. Bonini and A. Bondanza: CD44v6-targeted T cells mediate potent antitumor effects against acute myeloid leukemia and multiple myeloma. Blood, 122(20), 3461-72 (2013) doi:10.1182/blood-2013-04-493361

55. S. Peinert, H. M. Prince, P. M. Guru, M. H. Kershaw, M. J. Smyth, J. A. Trapani, P. Gambell, S. Harrison, A. M. Scott, F. E. Smyth, P. K. Darcy, K. Tainton, P. Neeson, D. S. Ritchie and D. Honemann: Gene-modified $\mathrm{T}$ cells as immunotherapy for multiple myeloma and acute myeloid leukemia expressing the Lewis Y antigen. Gene Ther, 17(5), 678-86 (2010) doi:10.1038/gt.2010.21

56. S. Nikiforow, L. Werner, J. Murad, M. Jacobs, L. Johnston, S. Patches, R. White, H. Daley, H. Negre, J. Reder, C. Sentman, T. Wade, A. Schmucker, F. F. Lehmann, S. Snykers, R. Allen, H. Dipietro, K. Cummings, I. Galinsky, N. C. Munshi, R. L. Schlossman, R. M. Stone, D. S. Neuberg, R. J. Soiffer, G. Dranoff, J. Ritz and S. H. C. Baumeister: Safety Data from a First-in-Human Phase 1 Trial of NKG2D Chimeric Antigen Receptor-T Cells in AML/MDS and Multiple Myeloma. Blood, 128(22), 4052-4052 (2016)

57. S. Venniyil Radhakrishnan, T. Luetkens, S. Yousef, N. Bhardwaj, M. N. Steinbach, J. Weidner, C. Shorter, D. W. Sborov and D. Atanackovic: Chimeric Antigen Receptor (CAR) T Cells Specific for CD229: A Potentially Curative Approach for Multiple Myeloma. Blood, 130(Suppl 1), 3142-3142 (2017)

58. N. Hosen, Y. Matsunaga, K. Hasegawa, H. Matsuno, Y. Nakamura, M. Makita, K. Watanabe, M. Yoshida, K. Satoh, S. Morimoto, F. Fujiki, H. Nakajima, J. Nakata, S. Nishida, A. Tsuboi, Y. Oka, M. Manabe, H. Ichihara, Y. Aoyama, A. Mugitani, T. Nakao, M. Hino, R. Uchibori, K. Ozawa, Y. Baba, S. Terakura, N. Wada, E. Morii, J. Nishimura, K. Takeda, Y. Oji, H. Sugiyama, J. Takagi and A. 
Kumanogoh: The activated conformation of integrin beta7 is a novel multiple myeloma-specific target for CAR T cell therapy. Nat Med, 23(12), 1436-1443 (2017) doi:10.1038/nm.4431

59. K. H. Chen, M. Wada, K. G. Pinz, H. Liu, K. W. Lin, A. Jares, A. E. Firor, X. Shuai, H. Salman, M. Golightly, F. Lan, L. Senzel, E. L. Leung, X. Jiang and Y. Ma: Preclinical targeting of aggressive Tcell malignancies using anti-CD5 chimeric antigen receptor. Leukemia, 31(10), 2151-2160 (2017) doi:10.1038/leu.2017.8

60. D. Gomes-Silva, M. Srinivasan, S. Sharma, C. M. Lee, D. L. Wagner, T. H. Davis, R. H. Rouce, G. Bao, M. K. Brenner and M. Mamonkin: CD7-edited T cells expressing a CD7-specific CAR for the therapy of T-cell malignancies. Blood, 130(3), 285-296 (2017) doi:10.1182/blood-2017-01-761320

61. P. M. Maciocia, P. A. Wawrzyniecka, B. Philip, I. Ricciardelli, A. U. Akarca, S. C. Onuoha, M. Legut, D. K. Cole, A. K. Sewell, G. Gritti, J. Somja, M. A. Piris, K. S. Peggs, D. C. Linch, T. Marafioti and M. A. Pule: Targeting the $\mathrm{T}$ cell receptor beta-chain constant region for immunotherapy of $\mathrm{T}$ cell malignancies. Nat Med, 23(12), 1416-1423 (2017) doi:10.1038/nm.4444

62. A. Younes, N. L. Bartlett, J. P. Leonard, D. A. Kennedy, C. M. Lynch, E. L. Sievers and A. Forero-Torres: Brentuximab vedotin (SGN-35) for relapsed CD30-positive lymphomas. $N$ Engl J Med, 363(19), 1812-21 (2010) doi:10.1056/NEJMoa1002965

63. A. Younes and S. M. Ansell: Novel agents in the treatment of Hodgkin lymphoma: Biological basis and clinical results. Semin Hematol, 53(3), 186-9 (2016) doi:10.1053/j.seminhematol.2016.05.011 64. C. M. Wang, Z. Q. Wu, Y. Wang, Y. L. Guo, H. R. Dai, X. H. Wang, X. Li, Y. J. Zhang, W. Y. Zhang, M. X. Chen, Y. Zhang, K. C. Feng, Y. Liu, S. X. Li, Q. M. Yang and W. D. Han: Autologous T Cells Expressing CD30 Chimeric Antigen Receptors for Relapsed or Refractory Hodgkin Lymphoma: An Open-Label Phase I Trial. Clin Cancer Res, 23(5), 1156-1166 (2017) doi:10.1158/1078-0432.ccr16-1365

65. C. A. Ramos, B. Ballard, H. Zhang, O. Dakhova, A. P. Gee, Z. Mei, M. Bilgi, M. F. Wu, H. Liu, B. Grilley, C. M. Bollard, B. H. Chang, C. M. Rooney, M. K. Brenner, H. E. Heslop, G. Dotti and B. Savoldo: Clinical and immunological responses after CD30-specific chimeric antigen receptorredirected lymphocytes. J Clin Invest, 127(9), 3462-3471 (2017) doi:10.1172/jci94306

66. N. J. Short, M. E. Rytting and J. E. Cortes: Acute myeloid leukaemia. Lancet, 392(10147), 593606 (2018) doi:10.1016/s0140-6736(18)31041-9

67. S. K. Tasian: Acute myeloid leukemia chimeric antigen receptor T-cell immunotherapy: how far up the road have we traveled? Ther Adv Hematol, 9(6), 135-148 (2018) doi:10.1177/2040620718774268

68. K. D. Cummins and S. Gill: Will CAR T cell therapy have a role in AML? Promises and pitfalls. Seminars in Hematology (2018) doi:https://doi.org/10.1053/j.seminhematol.2018.08.008

69. A. Rotolo, A. Karadimitris and M. Ruella: Building upon the success of CART19: chimeric antigen receptor T cells for hematologic malignancies. Leuk Lymphoma, 59(9), 2040-2055 (2018) doi:10.1080/10428194.2017.1403024

70. K. D. Cummins, N. Frey, A. M. Nelson, A. Schmidt, S. Luger, R. E. Isaacs, S. F. Lacey, E. Hexner, J. J. Melenhorst, C. H. June, D. L. Porter and S. I. Gill: Treating Relapsed / Refractory (RR) AML with Biodegradable Anti-CD123 CAR Modified T Cells. Blood, 130(Suppl 1), 1359-1359 (2017) 71. S. K. Tasian, S. S. Kenderian, F. Shen, M. Ruella, O. Shestova, M. Kozlowski, Y. Li, A. Schrank-Hacker, J. J. D. Morrissette, M. Carroll, C. H. June, S. A. Grupp and S. Gill: Optimized depletion of chimeric antigen receptor $\mathrm{T}$ cells in murine xenograft models of human acute myeloid leukemia. Blood, 129(17), 2395-2407 (2017) doi:10.1182/blood-2016-08-736041

72. K. Minagawa, M. O. Jamil, M. Al-Obaidi, L. Pereboeva, D. Salzman, H. P. Erba, L. S. Lamb, R. Bhatia, S. Mineishi and A. Di Stasi: In Vitro Pre-Clinical Validation of Suicide Gene Modified AntiCD33 Redirected Chimeric Antigen Receptor T-Cells for Acute Myeloid Leukemia. PLoS One, 11(12), e0166891 (2016) doi:10.1371/journal.pone.0166891

73. M. Cartellieri, A. Feldmann, S. Koristka, C. Arndt, S. Loff, A. Ehninger, M. von Bonin, E. P. Bejestani, G. Ehninger and M. P. Bachmann: Switching CAR T cells on and off: a novel modular platform for retargeting of $\mathrm{T}$ cells to AML blasts. Blood Cancer J, 6(8), e458 (2016) doi:10.1038/bcj.2016.61

74. M. Y. Kim, K. R. Yu, S. S. Kenderian, M. Ruella, S. Chen, T. H. Shin, A. A. Aljanahi, D. Schreeder, M. Klichinsky, O. Shestova, M. S. Kozlowski, K. D. Cummins, X. Shan, M. Shestov, A. Bagg, J. J. D. Morrissette, P. Sekhri, C. R. Lazzarotto, K. R. Calvo, D. B. Kuhns, R. E. Donahue, G. K. 
Behbehani, S. Q. Tsai, C. E. Dunbar and S. Gill: Genetic Inactivation of CD33 in Hematopoietic Stem Cells to Enable CAR T Cell Immunotherapy for Acute Myeloid Leukemia. Cell, 173(6), 1439-1453 e19 (2018) doi:10.1016/j.cell.2018.05.013

75. F. Perna, S. H. Berman, R. K. Soni, J. Mansilla-Soto, J. Eyquem, M. Hamieh, R. C. Hendrickson, C. W. Brennan and M. Sadelain: Integrating Proteomics and Transcriptomics for Systematic Combinatorial Chimeric Antigen Receptor Therapy of AML. Cancer Cell, 32(4), 506-519 e5 (2017) doi:10.1016/j.ccell.2017.09.004

76. Y. Akahori, L. Wang, M. Yoneyama, N. Seo, S. Okumura, Y. Miyahara, Y. Amaishi, S. Okamoto, J. Mineno, H. Ikeda, T. Maki, H. Fujiwara, Y. Akatsuka, T. Kato and H. Shiku: Antitumor activity of CAR-T cells targeting the intracellular oncoprotein WT1 can be enhanced by vaccination. Blood, 132(11), 1134-1145 (2018) doi:10.1182/blood-2017-08-802926

77. K. D. Cummins and S. Gill: Anti-CD123 chimeric antigen receptor T-cells (CART): an evolving treatment strategy for hematological malignancies, and a potential ace-in-the-hole against antigennegative relapse. Leuk Lymphoma, 59(7), 1539-1553 (2018) doi:10.1080/10428194.2017.1375107

78. S. Haubner, F. Perna, T. Kohnke, C. Schmidt, S. Berman, C. Augsberger, F. M. Schnorfeil, C. Krupka, F. S. Lichtenegger, X. Liu, P. Kerbs, S. Schneider, K. H. Metzeler, K. Spiekermann, W. Hiddemann, P. A. Greif, T. Herold, M. Sadelain and M. Subklewe: Coexpression profile of leukemic stem cell markers for combinatorial targeted therapy in AML. Leukemia (2018) doi:10.1038/s41375018-0180-3

79. H. Jetani, I. Garcia-Cadenas, T. Nerreter, S. Thomas, J. Rydzek, J. B. Meijide, H. Bonig, W. Herr, J. Sierra, H. Einsele and M. Hudecek: CAR T-cells targeting FLT3 have potent activity against FLT3(-)ITD(+) AML and act synergistically with the FLT3-inhibitor crenolanib. Leukemia, 32(5), 1168-1179 (2018) doi:10.1038/s41375-018-0009-0

80. H. Jetani, I. García-Cadenas, T. Nerreter, J. Rydzek, S. Thomas, W. Herr, J. Sierra, H. Bönig, H. Einsele and M. Hudecek: CAR T Cells Targeting FLT3 on AML Confer Potent Anti-Leukemic Activity and Act Synergistically with the FLT3 Inhibitor Midostaurin. Blood, 130(Suppl 1), 1351-1351 (2017)

81. W. Zheng, C. E. O'Hear, R. Alli, J. H. Basham, H. A. Abdelsamed, L. E. Palmer, L. L. Jones, B. Youngblood and T. L. Geiger: PI3K orchestration of the in vivo persistence of chimeric antigen receptor-modified T cells. Leukemia, 32(5), 1157-1167 (2018) doi:10.1038/s41375-017-0008-6

82. D. S. Ritchie, P. J. Neeson, A. Khot, S. Peinert, T. Tai, K. Tainton, K. Chen, M. Shin, D. M. Wall, D. Honemann, P. Gambell, D. A. Westerman, J. Haurat, J. A. Westwood, A. M. Scott, L. Kravets, M. Dickinson, J. A. Trapani, M. J. Smyth, P. K. Darcy, M. H. Kershaw and H. M. Prince: Persistence and efficacy of second generation CAR T cell against the LeY antigen in acute myeloid leukemia. Mol Ther, 21(11), 2122-9 (2013) doi:10.1038/mt.2013.154

83. S. Li, Z. Tao, Y. Xu, J. Liu, N. An, Y. Wang, H. Xing, Z. Tian, K. Tang, X. Liao, Q. Rao, M. Wang and J. Wang: CD33-Specific Chimeric Antigen Receptor T Cells with Different Co-Stimulators Showed Potent Anti-Leukemia Efficacy and Different Phenotype. Hum Gene Ther, 29(5), 626-639 (2018) doi:10.1089/hum.2017.241

84. Q. S. Wang, Y. Wang, H. Y. Lv, Q. W. Han, H. Fan, B. Guo, L. L. Wang and W. D. Han: Treatment of CD33-directed chimeric antigen receptor-modified T cells in one patient with relapsed and refractory acute myeloid leukemia. Mol Ther, 23(1), 184-91 (2015) doi:10.1038/mt.2014.164

85. Y. Luo, L.-J. Chang, Y. Hu, L. Dong, G. Wei and H. Huang: First-in-Man CD123-Specific Chimeric Antigen Receptor-Modified T Cells for the Treatment of Refractory Acute Myeloid Leukemia. Blood, 126(23), 3778-3778 (2015)

86. L. Budde, J. Y. Song, Y. Kim, S. Blanchard, J. Wagner, A. S. Stein, L. Weng, M. Del Real, R. Hernandez, E. Marcucci, J. K. Shepphird, X. Wang, B. Wood, G. Marcucci, C. E. Brown and S. J. Forman: Remissions of Acute Myeloid Leukemia and Blastic Plasmacytoid Dendritic Cell Neoplasm Following Treatment with CD123-Specific CAR T Cells: A First-in-Human Clinical Trial. Blood, 130(Suppl 1), 811-811 (2017)

87. W. Zhang, B. M. Stevens, E. E. Budde, S. J. Forman, C. T. Jordan and E. Purev: Anti-CD123 CAR T-Cell Therapy for the Treatment of Myelodysplastic Syndrome. Blood, 130(Suppl 1), 1917-1917 (2017)

88. O. Beyar-Katz and S. Gill: Novel Approaches to Acute Myeloid Leukemia Immunotherapy. Clin Cancer Res (2018) doi:10.1158/1078-0432.ccr-17-3016 
89. J. M. Murad, S. H. Baumeister, L. Werner, H. Daley, H. Trebeden-Negre, J. Reder, C. L. Sentman, D. Gilham, F. Lehmann, S. Snykers, M. L. Sentman, T. Wade, A. Schmucker, M. W. Fanger, G. Dranoff, J. Ritz and S. Nikiforow: Manufacturing development and clinical production of NKG2D chimeric antigen receptor-expressing T cells for autologous adoptive cell therapy. Cytotherapy, 20(7), 952-963 (2018) doi:10.1016/j.jcyt.2018.05.001

90. D. A. Sallman, J. Brayer, E. M. Sagatys, C. Lonez, E. Breman, S. Agaugue, B. Verma, D. E. Gilham, F. F. Lehmann and M. L. Davila: NKG2D-based chimeric antigen receptor therapy induced remission in a relapsed/refractory acute myeloid leukemia patient. Haematologica, 103(9), e424-e426 (2018) doi:10.3324/haematol.2017.186742

91. F. Liu, K. Pinz, Y. Ma, M. Wada, K. Chen, G. Ma, Y. Su, S. Zhang, G. He and Y. Ma: First-InHuman Cll1-Cd33 Compound Car T Cells As A Two-Pronged Approach For The Treatment Of Refractory Acute Myeloid Leukemia. In: EHA. (2018)

92. R. C. Lynn, M. Poussin, A. Kalota, Y. Feng, P. S. Low, D. S. Dimitrov and D. J. Powell, Jr.: Targeting of folate receptor beta on acute myeloid leukemia blasts with chimeric antigen receptorexpressing T cells. Blood, 125(22), 3466-76 (2015) doi:10.1182/blood-2014-11-612721

93. D. Silva, H. Tashiro, M. Srinivasan, M. K. Brenner and M. Mamonkin: CD7 CAR for the Treatment of Acute Myeloid and Lymphoid Leukemia. Blood, 128(22), 4555-4555 (2016)

94. T. Yoshida, K. Mihara, Y. Takei, K. Yanagihara, T. Kubo, J. Bhattacharyya, C. Imai, T. Mino, Y. Takihara and T. Ichinohe: All-trans retinoic acid enhances cytotoxic effect of T cells with an antiCD38 chimeric antigen receptor in acute myeloid leukemia. Clin Transl Immunology, 5(12), e116 (2016) doi:10.1038/cti.2016.73

95. E. Laborda, M. Mazagova, S. Shao, X. Wang, H. Quirino, A. K. Woods, E. N. Hampton, D. T. Rodgers, C. H. Kim, P. G. Schultz and T. S. Young: Development of A Chimeric Antigen Receptor Targeting C-Type Lectin-Like Molecule-1 for Human Acute Myeloid Leukemia. Int J Mol Sci, 18(11) (2017) doi:10.3390/ijms18112259

96. L. Chen, H. Mao, J. Zhang, J. Chu, S. Devine, M. A. Caligiuri and J. Yu: Targeting FLT3 by chimeric antigen receptor T cells for the treatment of acute myeloid leukemia. Leukemia, 31(8), 18301834 (2017) doi:10.1038/leu.2017.147

97. S. John, H. Chen, M. Deng, X. Gui, G. Wu, W. Chen, Z. Li, N. Zhang, Z. An and C. C. Zhang: A Novel Anti-LILRB4 CAR-T Cell for the Treatment of Monocytic AML. Mol Ther, 26(10), 24872495 (2018) doi:10.1016/j.ymthe.2018.08.001

98. H. M. Knochelmann, A. S. Smith, C. J. Dwyer, M. M. Wyatt, S. Mehrotra and C. M. Paulos: CAR T Cells in Solid Tumors: Blueprints for Building Effective Therapies. Front Immunol, 9, 1740 (2018) doi:10.3389/fimmu.2018.01740

99. R. A. Morgan, J. C. Yang, M. Kitano, M. E. Dudley, C. M. Laurencot and S. A. Rosenberg: Case report of a serious adverse event following the administration of $\mathrm{T}$ cells transduced with a chimeric antigen receptor recognizing ERBB2. Mol Ther, 18(4), 843-51 (2010) doi:10.1038/mt.2010.24

100. C. H. Lamers, S. Sleijfer, S. van Steenbergen, P. van Elzakker, B. van Krimpen, C. Groot, A. Vulto, M. den Bakker, E. Oosterwijk, R. Debets and J. W. Gratama: Treatment of metastatic renal cell carcinoma with CAIX CAR-engineered T cells: clinical evaluation and management of on-target toxicity. Mol Ther, 21(4), 904-12 (2013) doi:10.1038/mt.2013.17

101. F. C. Thistlethwaite, D. E. Gilham, R. D. Guest, D. G. Rothwell, M. Pillai, D. J. Burt, A. J. Byatte, N. Kirillova, J. W. Valle, S. K. Sharma, K. A. Chester, N. B. Westwood, S. E. R. Halford, S. Nabarro, S. Wan, E. Austin and R. E. Hawkins: The clinical efficacy of first-generation carcinoembryonic antigen (CEACAM5)-specific CAR $\mathrm{T}$ cells is limited by poor persistence and transient pre-conditioning-dependent respiratory toxicity. Cancer Immunol Immunother, 66(11), 14251436 (2017) doi:10.1007/s00262-017-2034-7

102. K. C. Feng, Y. L. Guo, Y. Liu, H. R. Dai, Y. Wang, H. Y. Lv, J. H. Huang, Q. M. Yang and W. D. Han: Cocktail treatment with EGFR-specific and CD133-specific chimeric antigen receptor-modified $\mathrm{T}$ cells in a patient with advanced cholangiocarcinoma. J Hematol Oncol, 10(1), 4 (2017) doi:10.1186/s13045-016-0378-7

103. M. A. Morgan and A. Schambach: Chimeric Antigen Receptor T Cells: Extending Translation from Liquid to Solid Tumors. Hum Gene Ther, 29(10), 1083-1097 (2018) doi:10.1089/hum.2017.251

104. M. M. D'Aloia, I. G. Zizzari, B. Sacchetti, L. Pierelli and M. Alimandi: CAR-T cells: the long and winding road to solid tumors. Cell Death Dis, 9(3), 282 (2018) doi:10.1038/s41419-018-0278-6 
105. G. L. Beatty, M. H. O'Hara, S. F. Lacey, D. A. Torigian, F. Nazimuddin, F. Chen, I. M. Kulikovskaya, M. C. Soulen, M. McGarvey, A. M. Nelson, W. L. Gladney, B. L. Levine, J. J. Melenhorst, G. Plesa and C. H. June: Activity of Mesothelin-Specific Chimeric Antigen Receptor T Cells Against Pancreatic Carcinoma Metastases in a Phase 1 Trial. Gastroenterology, 155(1), 29-32 (2018) doi:10.1053/j.gastro.2018.03.029

106. S. C. Katz, G. R. Point, M. Cunetta, M. Thorn, P. Guha, N. J. Espat, C. Boutros, N. Hanna and R. P. Junghans: Regional CAR-T cell infusions for peritoneal carcinomatosis are superior to systemic delivery. Cancer Gene Ther, 23(5), 142-8 (2016) doi:10.1038/cgt.2016.14

107. H. Liu, Y. Xu, J. Xiang, L. Long, S. Green, Z. Yang, B. Zimdahl, J. Lu, N. Cheng, L. H. Horan, B. Liu, S. Yan, P. Wang, J. Diaz, L. Jin, Y. Nakano, J. F. Morales, P. Zhang, L. X. Liu, B. K. Staley, S. J. Priceman, C. E. Brown, S. J. Forman, V. W. Chan and C. Liu: Targeting Alpha-Fetoprotein (AFP)MHC Complex with CAR T-Cell Therapy for Liver Cancer. Clin Cancer Res, 23(2), 478-488 (2017) doi:10.1158/1078-0432.ccr-16-1203

108. S. C. Katz, R. A. Burga, E. McCormack, L. J. Wang, W. Mooring, G. R. Point, P. D. Khare, M. Thorn, Q. Ma, B. F. Stainken, E. O. Assanah, R. Davies, N. J. Espat and R. P. Junghans: Phase I Hepatic Immunotherapy for Metastases Study of Intra-Arterial Chimeric Antigen Receptor-Modified T-cell Therapy for CEA+ Liver Metastases. Clin Cancer Res, 21(14), 3149-59 (2015) doi:10.1158/10780432.ccr-14-1421

109. E. K. Moon, C. Carpenito, J. Sun, L. C. Wang, V. Kapoor, J. Predina, D. J. Powell, Jr., J. L. Riley, C. H. June and S. M. Albelda: Expression of a functional CCR2 receptor enhances tumor localization and tumor eradication by retargeted human $\mathrm{T}$ cells expressing a mesothelin-specific chimeric antibody receptor. Clin Cancer Res, 17(14), 4719-30 (2011) doi:10.1158/1078-0432.ccr-110351

110. S. Wilkie, M. C. van Schalkwyk, S. Hobbs, D. M. Davies, S. J. van der Stegen, A. C. Pereira, S. E. Burbridge, C. Box, S. A. Eccles and J. Maher: Dual targeting of ErbB2 and MUC1 in breast cancer using chimeric antigen receptors engineered to provide complementary signaling. J Clin Immunol, 32(5), 1059-70 (2012) doi:10.1007/s10875-012-9689-9

111. M. Hegde, M. Mukherjee, Z. Grada, A. Pignata, D. Landi, S. A. Navai, A. Wakefield, K. Fousek, K. Bielamowicz, K. K. Chow, V. S. Brawley, T. T. Byrd, S. Krebs, S. Gottschalk, W. S. Wels, M. L. Baker, G. Dotti, M. Mamonkin, M. K. Brenner, J. S. Orange and N. Ahmed: Tandem CAR T cells targeting HER2 and IL13Ralpha2 mitigate tumor antigen escape. J Clin Invest, 126(8), 3036-52 (2016) doi: $10.1172 /$ jci83416

112. K. Bielamowicz, K. Fousek, T. T. Byrd, H. Samaha, M. Mukherjee, N. Aware, M. F. Wu, J. S. Orange, P. Sumazin, T. K. Man, S. K. Joseph, M. Hegde and N. Ahmed: Trivalent CAR T cells overcome interpatient antigenic variability in glioblastoma. Neuro Oncol, 20(4), 506-518 (2018) doi:10.1093/neuonc/nox182

113. E. Zhang, P. Yang, J. Gu, H. Wu, X. Chi, C. Liu, Y. Wang, J. Xue, W. Qi, Q. Sun, S. Zhang, J. $\mathrm{Hu}$ and $\mathrm{H}$. Xu: Recombination of a dual-CAR-modified T lymphocyte to accurately eliminate pancreatic malignancy. J Hematol Oncol, 11(1), 102 (2018) doi:10.1186/s13045-018-0646-9

114. E. Lanitis, M. Poussin, A. W. Klattenhoff, D. Song, R. Sandaltzopoulos, C. H. June and D. J. Powell, Jr.: Chimeric antigen receptor T Cells with dissociated signaling domains exhibit focused antitumor activity with reduced potential for toxicity in vivo. Cancer Immunol Res, 1(1), 43-53 (2013) doi:10.1158/2326-6066.cir-13-0008

115. V. D. Fedorov, M. Themeli and M. Sadelain: PD-1- and CTLA-4-based inhibitory chimeric antigen receptors (iCARs) divert off-target immunotherapy responses. Sci Transl Med, 5(215), 215ra172 (2013) doi:10.1126/scitranslmed.3006597

116. M. Castellarin, K. Watanabe, C. H. June, C. C. Kloss and A. D. Posey, Jr.: Driving cars to the clinic for solid tumors. Gene Ther, 25(3), 165-175 (2018) doi:10.1038/s41434-018-0007-x

117. M. Koneru, T. J. Purdon, D. Spriggs, S. Koneru and R. J. Brentjens: IL-12 secreting tumortargeted chimeric antigen receptor T cells eradicate ovarian tumors in vivo. Oncoimmunology, 4(3), e994446 (2015) doi:10.4161/2162402x.2014.994446

118. L. Zhang, R. A. Morgan, J. D. Beane, Z. Zheng, M. E. Dudley, S. H. Kassim, A. V. Nahvi, L. T. Ngo, R. M. Sherry, G. Q. Phan, M. S. Hughes, U. S. Kammula, S. A. Feldman, M. A. Toomey, S. P. Kerkar, N. P. Restifo, J. C. Yang and S. A. Rosenberg: Tumor-infiltrating lymphocytes genetically 
engineered with an inducible gene encoding interleukin-12 for the immunotherapy of metastatic melanoma. Clin Cancer Res, 21(10), 2278-88 (2015) doi:10.1158/1078-0432.ccr-14-2085

119. M. P. Avanzi, O. Yeku, X. Li, D. P. Wijewarnasuriya, D. G. van Leeuwen, K. Cheung, H. Park, T. J. Purdon, A. F. Daniyan, M. H. Spitzer and R. J. Brentjens: Engineered Tumor-Targeted T Cells Mediate Enhanced Anti-Tumor Efficacy Both Directly and through Activation of the Endogenous Immune System. Cell Rep, 23(7), 2130-2141 (2018) doi:10.1016/j.celrep.2018.04.051

120. K. Adachi, Y. Kano, T. Nagai, N. Okuyama, Y. Sakoda and K. Tamada: IL-7 and CCL19 expression in CAR-T cells improves immune cell infiltration and CAR-T cell survival in the tumor. Nat Biotechnol, 36(4), 346-351 (2018) doi:10.1038/nbt.4086

121. C. C. Kloss, J. Lee, A. Zhang, F. Chen, J. J. Melenhorst, S. F. Lacey, M. V. Maus, J. A. Fraietta, Y. Zhao and C. H. June: Dominant-Negative TGF-beta Receptor Enhances PSMA-Targeted Human CAR T Cell Proliferation And Augments Prostate Cancer Eradication. Mol Ther, 26(7), 1855-1866 (2018) doi:10.1016/j.ymthe.2018.05.003

122. I. Caruana, B. Savoldo, V. Hoyos, G. Weber, H. Liu, E. S. Kim, M. M. Ittmann, D. Marchetti and G. Dotti: Heparanase promotes tumor infiltration and antitumor activity of CAR-redirected T lymphocytes. Nat Med, 21(5), 524-9 (2015) doi:10.1038/nm.3833

123. L. M. Whilding, S. Vallath and J. Maher: The integrin alphavbeta6: a novel target for CAR Tcell immunotherapy? Biochem Soc Trans, 44(2), 349-55 (2016) doi:10.1042/bst20150249

124. A. Rosewell Shaw and M. Suzuki: Oncolytic Viruses Partner With T-Cell Therapy for Solid Tumor Treatment. Front Immunol, 9, 2103 (2018) doi:10.3389/fimmu.2018.02103

125. L. B. John, C. Devaud, C. P. Duong, C. S. Yong, P. A. Beavis, N. M. Haynes, M. T. Chow, M. J. Smyth, M. H. Kershaw and P. K. Darcy: Anti-PD-1 antibody therapy potently enhances the eradication of established tumors by gene-modified T cells. Clin Cancer Res, 19(20), 5636-46 (2013) doi:10.1158/1078-0432.ccr-13-0458

126. L. Cherkassky, A. Morello, J. Villena-Vargas, Y. Feng, D. S. Dimitrov, D. R. Jones, M. Sadelain and P. S. Adusumilli: Human CAR T cells with cell-intrinsic PD-1 checkpoint blockade resist tumormediated inhibition. J Clin Invest, 126(8), 3130-44 (2016) doi:10.1172/jci83092

127. A. Heczey, C. U. Louis, B. Savoldo, O. Dakhova, A. Durett, B. Grilley, H. Liu, M. F. Wu, Z. Mei, A. Gee, B. Mehta, H. Zhang, N. Mahmood, H. Tashiro, H. E. Heslop, G. Dotti, C. M. Rooney and M. K. Brenner: CAR T Cells Administered in Combination with Lymphodepletion and PD-1 Inhibition to Patients with Neuroblastoma. Mol Ther, 25(9), 2214-2224 (2017) doi:10.1016/j.ymthe.2017.05.012 128. D. H. Yoon, M. J. Osborn, J. Tolar and C. J. Kim: Incorporation of Immune Checkpoint Blockade into Chimeric Antigen Receptor T Cells (CAR-Ts): Combination or Built-In CAR-T. Int J Mol Sci, 19(2) (2018) doi:10.3390/ijms19020340

129. S. Li, N. Siriwon, X. Zhang, S. Yang, T. Jin, F. He, Y. J. Kim, J. Mac, Z. Lu, S. Wang, X. Han and P. Wang: Enhanced Cancer Immunotherapy by Chimeric Antigen Receptor-Modified T Cells Engineered to Secrete Checkpoint Inhibitors. Clin Cancer Res, 23(22), 6982-6992 (2017) doi:10.1158/1078-0432.ccr-17-0867

130. S. Rafiq, O. O. Yeku, H. J. Jackson, T. J. Purdon, D. G. van Leeuwen, D. J. Drakes, M. Song, M. M. Miele, Z. Li, P. Wang, S. Yan, J. Xiang, X. Ma, V. E. Seshan, R. C. Hendrickson, C. Liu and R. J. Brentjens: Targeted delivery of a PD-1-blocking scFv by CAR-T cells enhances anti-tumor efficacy in vivo. Nat Biotechnol, 36(9), 847-856 (2018) doi:10.1038/nbt.4195

131. X. Liu, R. Ranganathan, S. Jiang, C. Fang, J. Sun, S. Kim, K. Newick, A. Lo, C. H. June, Y. Zhao and E. K. Moon: A Chimeric Switch-Receptor Targeting PD1 Augments the Efficacy of SecondGeneration CAR T Cells in Advanced Solid Tumors. Cancer Res, 76(6), 1578-90 (2016) doi:10.1158/0008-5472.can-15-2524

132. B. Hu, Y. Zou, L. Zhang, J. Tang, G. Niedermann, E. Firat, X. Huang and X. Zhu: Nucleofection with Plasmid DNA for CRISPR/Cas9-Mediated Inactivation of Programmed Cell Death Protein 1 in CD133-Specific CAR T Cells. Hum Gene Ther (2018) doi:10.1089/hum.2017.234

133. J. Li, W. Li, K. Huang, Y. Zhang, G. Kupfer and Q. Zhao: Chimeric antigen receptor T cell (CAR-T) immunotherapy for solid tumors: lessons learned and strategies for moving forward. $J$ Hematol Oncol, 11(1), 22 (2018) doi:10.1186/s13045-018-0568-6

134. N. Ahmed, V. S. Brawley, M. Hegde, C. Robertson, A. Ghazi, C. Gerken, E. Liu, O. Dakhova, A. Ashoori, A. Corder, T. Gray, M. F. Wu, H. Liu, J. Hicks, N. Rainusso, G. Dotti, Z. Mei, B. Grilley, A. Gee, C. M. Rooney, M. K. Brenner, H. E. Heslop, W. S. Wels, L. L. Wang, P. Anderson and S. 
Gottschalk: Human Epidermal Growth Factor Receptor 2 (HER2) -Specific Chimeric Antigen ReceptorModified T Cells for the Immunotherapy of HER2-Positive Sarcoma. J Clin Oncol, 33(15), 1688-96 (2015) doi:10.1200/jco.2014.58.0225

135. M. Hegde, C. C. DeRenzo, H. Zhang, M. Mata, C. Gerken, A. Shree, Z. Yi, V. Brawley, O. Dakhova, M.-F. Wu, H. Liu, J. Hicks, B. Grilley, A. P. Gee, C. M. Rooney, M. K. Brenner, H. E. Heslop, W. Wels, S. Gottschalk and N. M. Ahmed: Expansion of HER2-CAR T cells after lymphodepletion and clinical responses in patients with advanced sarcoma. Journal of Clinical Oncology, 35(15_suppl), 10508-10508 (2017) doi:10.1200/JCO.2017.35.15_suppl.10508

136. C. U. Louis, B. Savoldo, G. Dotti, M. Pule, E. Yvon, G. D. Myers, C. Rossig, H. V. Russell, O. Diouf, E. Liu, H. Liu, M. F. Wu, A. P. Gee, Z. Mei, C. M. Rooney, H. E. Heslop and M. K. Brenner: Antitumor activity and long-term fate of chimeric antigen receptor-positive $\mathrm{T}$ cells in patients with neuroblastoma. Blood, 118(23), 6050-6 (2011) doi:10.1182/blood-2011-05-354449

137. C. Zhang, Z. Wang, Z. Yang, M. Wang, S. Li, Y. Li, R. Zhang, Z. Xiong, Z. Wei, J. Shen, Y. Luo, Q. Zhang, L. Liu, H. Qin, W. Liu, F. Wu, W. Chen, F. Pan, X. Zhang, P. Bie, H. Liang, G. Pecher and C. Qian: Phase I Escalating-Dose Trial of CAR-T Therapy Targeting CEA(+) Metastatic Colorectal Cancers. Mol Ther, 25(5), 1248-1258 (2017) doi:10.1016/j.ymthe.2017.03.010

138. B. Zhai, D. Shi, H. Gao, X. Qi, H. Jiang, Y. Zhang, J. Chi, H. Ruan, H. Wang, Q. C. Ru and Z. Li: A phase I study of anti-GPC3 chimeric antigen receptor modified T cells (GPC3 CAR-T) in Chinese patients with refractory or relapsed GPC3+ hepatocellular carcinoma ( $\mathrm{r} / \mathrm{r}$ GPC3+ HCC). Journal of Clinical Oncology, 35(15_suppl), 3049-3049 (2017) doi:10.1200/JCO.2017.35.15_suppl.3049

139. Y. Wang, M. Chen, Z. Wu, C. Tong, H. Dai, Y. Guo, Y. Liu, J. Huang, H. Lv, C. Luo, K. C. Feng, Q. M. Yang, X. L. Li and W. Han: CD133-directed CAR T cells for advanced metastasis malignancies: A phase I trial. Oncoimmunology, 7(7), e1440169 (2018) doi:10.1080/2162402x.2018.1440169

140. S. Papa, A. Adami, M. Metoudi, D. Achkova, M. v. Schalkwyk, A. P. Pereira, L. BosshardCarter, L. Whilding, S. v. d. Stegen, D. Davies, F. Farzaneh, T. G. Urbano, J.-P. Jeannon, J. F. Spicer and J. Maher: A phase I trial of T4 CAR T-cell immunotherapy in head and neck squamous cancer (HNSCC). Journal of Clinical Oncology, 36(15_suppl), 3046-3046 (2018) doi:10.1200/JCO.2018.36.15_suppl.3046

141. S. J. Bagley, A. S. Desai, G. P. Linette, C. H. June and D. M. O'Rourke: CAR T-cell therapy for glioblastoma: recent clinical advances and future challenges. Neuro Oncol, 20(11), 1429-1438 (2018) doi:10.1093/neuonc/noy032

142. D. M. O'Rourke, M. P. Nasrallah, A. Desai, J. J. Melenhorst, K. Mansfield, J. J. D. Morrissette, M. Martinez-Lage, S. Brem, E. Maloney, A. Shen, R. Isaacs, S. Mohan, G. Plesa, S. F. Lacey, J. M. Navenot, Z. Zheng, B. L. Levine, H. Okada, C. H. June, J. L. Brogdon and M. V. Maus: A single dose of peripherally infused EGFRvIII-directed CAR T cells mediates antigen loss and induces adaptive resistance in patients with recurrent glioblastoma. Sci Transl Med, 9(399) (2017) doi:10.1126/scitranslmed.aaa0984

143. N. Ahmed, V. Brawley, M. Hegde, K. Bielamowicz, M. Kalra, D. Landi, C. Robertson, T. L. Gray, O. Diouf, A. Wakefield, A. Ghazi, C. Gerken, Z. Yi, A. Ashoori, M. F. Wu, H. Liu, C. Rooney, G. Dotti, A. Gee, J. Su, Y. Kew, D. Baskin, Y. J. Zhang, P. New, B. Grilley, M. Stojakovic, J. Hicks, S. Z. Powell, M. K. Brenner, H. E. Heslop, R. Grossman, W. S. Wels and S. Gottschalk: HER2-Specific Chimeric Antigen Receptor-Modified Virus-Specific T Cells for Progressive Glioblastoma: A Phase 1 Dose-Escalation Trial. JAMA Oncol, 3(8), 1094-1101 (2017) doi:10.1001/jamaoncol.2017.0184

144. A. Nellan, C. Rota, R. Majzner, C. M. Lester-McCully, A. M. Griesinger, J. M. Mulcahy Levy, N. K. Foreman, K. E. Warren and D. W. Lee: Durable regression of Medulloblastoma after regional and intravenous delivery of anti-HER2 chimeric antigen receptor T cells. J Immunother Cancer, 6(1), 30 (2018) doi:10.1186/s40425-018-0340-z

145. S. J. Priceman, D. Tilakawardane, B. Jeang, B. Aguilar, J. P. Murad, A. K. Park, W. C. Chang, J. R. Ostberg, J. Neman, R. Jandial, J. Portnow, S. J. Forman and C. E. Brown: Regional Delivery of Chimeric Antigen Receptor-Engineered T Cells Effectively Targets HER2(+) Breast Cancer Metastasis to the Brain. Clin Cancer Res, 24(1), 95-105 (2018) doi:10.1158/1078-0432.ccr-17-2041

146. C. W. Mount, R. G. Majzner, S. Sundaresh, E. P. Arnold, M. Kadapakkam, S. Haile, L. Labanieh, E. Hulleman, P. J. Woo, S. P. Rietberg, H. Vogel, M. Monje and C. L. Mackall: Potent 
antitumor efficacy of anti-GD2 CAR T cells in H3-K27M(+) diffuse midline gliomas. Nat Med, 24(5), 572-579 (2018) doi:10.1038/s41591-018-0006-x

147. C. E. Brown, B. Badie, M. E. Barish, L. Weng, J. R. Ostberg, W. C. Chang, A. Naranjo, R. Starr, J. Wagner, C. Wright, Y. Zhai, J. R. Bading, J. A. Ressler, J. Portnow, M. D'Apuzzo, S. J. Forman and M. C. Jensen: Bioactivity and Safety of IL13Ralpha2-Redirected Chimeric Antigen Receptor CD8+ $\mathrm{T}$ Cells in Patients with Recurrent Glioblastoma. Clin Cancer Res, 21(18), 4062-72 (2015) doi:10.1158/1078-0432.ccr-15-0428

148. C. E. Brown, D. Alizadeh, R. Starr, L. Weng, J. R. Wagner, A. Naranjo, J. R. Ostberg, M. S. Blanchard, J. Kilpatrick, J. Simpson, A. Kurien, S. J. Priceman, X. Wang, T. L. Harshbarger, M. D'Apuzzo, J. A. Ressler, M. C. Jensen, M. E. Barish, M. Chen, J. Portnow, S. J. Forman and B. Badie: Regression of Glioblastoma after Chimeric Antigen Receptor T-Cell Therapy. N Engl J Med, 375(26), 2561-9 (2016) doi:10.1056/NEJMoa1610497

149. T. Giavridis, S. J. C. van der Stegen, J. Eyquem, M. Hamieh, A. Piersigilli and M. Sadelain: CAR $\mathrm{T}$ cell-induced cytokine release syndrome is mediated by macrophages and abated by IL-1 blockade. Nat Med, 24(6), 731-738 (2018) doi:10.1038/s41591-018-0041-7

150. M. Norelli, B. Camisa, G. Barbiera, L. Falcone, A. Purevdorj, M. Genua, F. Sanvito, M. Ponzoni, C. Doglioni, P. Cristofori, C. Traversari, C. Bordignon, F. Ciceri, R. Ostuni, C. Bonini, M. Casucci and A. Bondanza: Monocyte-derived IL-1 and IL-6 are differentially required for cytokinerelease syndrome and neurotoxicity due to CAR T cells. Nat Med, 24(6), 739-748 (2018) doi:10.1038/s41591-018-0036-4

151. J. H. Park, I. Riviere, M. Gonen, X. Wang, B. Senechal, K. J. Curran, C. Sauter, Y. Wang, B. Santomasso, E. Mead, M. Roshal, P. Maslak, M. Davila, R. J. Brentjens and M. Sadelain: Long-Term Follow-up of CD19 CAR Therapy in Acute Lymphoblastic Leukemia. N Engl J Med, 378(5), 449-459 (2018) doi:10.1056/NEJMoa1709919

152. J. S. Abramson, T. Siddiqi, M. L. Palomba, L. I. Gordon, M. A. Lunning, J. E. Arnason, M. Wang, A. Forero-Torres, T. Albertson, C. Dehner, J. Garcia, D. Li, B. Xie and D. G. Maloney: High durable CR rates and preliminary safety profile for JCAR017 in R/R aggressive b-NHL (TRANSCEND NHL 001 Study): A defined composition CD19-directed CAR T-cell product with potential for outpatient administration. Journal of Clinical Oncology, 36(5_suppl), 120-120 (2018) doi:10.1200/JCO.2018.36.5_suppl.120

153. A. Taraseviciute, V. Tkachev, R. Ponce, C. J. Turtle, J. M. Snyder, H. D. Liggitt, D. Myerson, L. Gonzalez-Cuyar, A. Baldessari, C. English, A. Yu, H. Zheng, S. N. Furlan, D. J. Hunt, V. Hoglund, O. Finney, H. Brakke, B. R. Blazar, C. Berger, S. R. Riddell, R. Gardner, L. S. Kean and M. C. Jensen: Chimeric Antigen Receptor T Cell-Mediated Neurotoxicity in Nonhuman Primates. Cancer Discov, 8(6), 750-763 (2018) doi:10.1158/2159-8290.cd-17-1368

154. J. Gust, K. A. Hay, L. A. Hanafi, D. Li, D. Myerson, L. F. Gonzalez-Cuyar, C. Yeung, W. C. Liles, M. Wurfel, J. A. Lopez, J. Chen, D. Chung, S. Harju-Baker, T. Ozpolat, K. R. Fink, S. R. Riddell, D. G. Maloney and C. J. Turtle: Endothelial Activation and Blood-Brain Barrier Disruption in Neurotoxicity after Adoptive Immunotherapy with CD19 CAR-T Cells. Cancer Discov, 7(12), 14041419 (2017) doi:10.1158/2159-8290.cd-17-0698

155. J. Harris: Kite Reports Cerebral Edema Death in ZUMA-1 CAR T-Cell Trial. In: OncLive. (2017)

156. S. S. Neelapu, S. Tummala, P. Kebriaei, W. Wierda, C. Gutierrez, F. L. Locke, K. V. Komanduri, Y. Lin, N. Jain, N. Daver, J. Westin, A. M. Gulbis, M. E. Loghin, J. F. de Groot, S. Adkins, S. E. Davis, K. Rezvani, P. Hwu and E. J. Shpall: Chimeric antigen receptor T-cell therapy - assessment and management of toxicities. Nat Rev Clin Oncol, 15(1), 47-62 (2018) doi:10.1038/nrclinonc.2017.148 157. H. J. Kolb: Graft-versus-leukemia effects of transplantation and donor lymphocytes. Blood, 112(12), 4371-83 (2008) doi:10.1182/blood-2008-03-077974

158. S. Z. Pavletic, S. Kumar, M. Mohty, M. de Lima, J. M. Foran, M. Pasquini, M. J. Zhang, S. Giralt, M. R. Bishop and D. Weisdorf: NCI First International Workshop on the Biology, Prevention, and Treatment of Relapse after Allogeneic Hematopoietic Stem Cell Transplantation: report from the Committee on the Epidemiology and Natural History of Relapse following Allogeneic Cell Transplantation. Biol Blood Marrow Transplant, 16(7), 871-90 (2010) doi:10.1016/j.bbmt.2010.04.004 
159. C. Roddie and K. S. Peggs: Donor lymphocyte infusion following allogeneic hematopoietic stem cell transplantation. Expert Opin Biol Ther, 11(4), 473-87 (2011) doi:10.1517/14712598.2011.554811

160. C. R. Cruz, K. P. Micklethwaite, B. Savoldo, C. A. Ramos, S. Lam, S. Ku, O. Diouf, E. Liu, A. J. Barrett, S. Ito, E. J. Shpall, R. A. Krance, R. T. Kamble, G. Carrum, C. M. Hosing, A. P. Gee, Z. Mei, B. J. Grilley, H. E. Heslop, C. M. Rooney, M. K. Brenner, C. M. Bollard and G. Dotti: Infusion of donorderived CD19-redirected virus-specific T cells for B-cell malignancies relapsed after allogeneic stem cell transplant: a phase 1 study. Blood, 122(17), 2965-73 (2013) doi:10.1182/blood-2013-06-506741

161. H. Dai, W. Zhang, X. Li, Q. Han, Y. Guo, Y. Zhang, Y. Wang, C. Wang, F. Shi, Y. Zhang, M. Chen, K. Feng, Q. Wang, H. Zhu, X. Fu, S. Li and W. Han: Tolerance and efficacy of autologous or donor-derived T cells expressing CD19 chimeric antigen receptors in adult B-ALL with extramedullary leukemia. Oncoimmunology, 4(11), e1027469 (2015) doi:10.1080/2162402x.2015.1027469

162. J. N. Brudno, R. P. Somerville, V. Shi, J. J. Rose, D. C. Halverson, D. H. Fowler, J. C. GeaBanacloche, S. Z. Pavletic, D. D. Hickstein, T. L. Lu, S. A. Feldman, A. T. Iwamoto, R. Kurlander, I. Maric, A. Goy, B. G. Hansen, J. S. Wilder, B. Blacklock-Schuver, F. T. Hakim, S. A. Rosenberg, R. E. Gress and J. N. Kochenderfer: Allogeneic T Cells That Express an Anti-CD19 Chimeric Antigen Receptor Induce Remissions of B-Cell Malignancies That Progress After Allogeneic Hematopoietic Stem-Cell Transplantation Without Causing Graft-Versus-Host Disease. J Clin Oncol, 34(10), 1112-21 (2016) doi:10.1200/jco.2015.64.5929

163. P. Kebriaei, H. Singh, M. H. Huls, M. J. Figliola, R. Bassett, S. Olivares, B. Jena, M. J. Dawson, P. R. Kumaresan, S. Su, S. Maiti, J. Dai, B. Moriarity, M. A. Forget, V. Senyukov, A. Orozco, T. Liu, J. McCarty, R. N. Jackson, J. S. Moyes, G. Rondon, M. Qazilbash, S. Ciurea, A. Alousi, Y. Nieto, K. Rezvani, D. Marin, U. Popat, C. Hosing, E. J. Shpall, H. Kantarjian, M. Keating, W. Wierda, K. A. Do, D. A. Largaespada, D. A. Lee, P. B. Hackett, R. E. Champlin and L. J. Cooper: Phase I trials using Sleeping Beauty to generate CD19-specific CAR T cells. J Clin Invest, 126(9), 3363-76 (2016) doi:10.1172/jci86721

164. D. W. Lee, J. N. Kochenderfer, M. Stetler-Stevenson, Y. K. Cui, C. Delbrook, S. A. Feldman, T. J. Fry, R. Orentas, M. Sabatino, N. N. Shah, S. M. Steinberg, D. Stroncek, N. Tschernia, C. Yuan, H. Zhang, L. Zhang, S. A. Rosenberg, A. S. Wayne and C. L. Mackall: T cells expressing CD19 chimeric antigen receptors for acute lymphoblastic leukaemia in children and young adults: a phase 1 doseescalation trial. Lancet, 385(9967), 517-528 (2015) doi:10.1016/s0140-6736(14)61403-3

165. R. A. Gardner, O. Finney, C. Annesley, H. Brakke, C. Summers, K. Leger, M. Bleakley, C. Brown, S. Mgebroff, K. S. Kelly-Spratt, V. Hoglund, C. Lindgren, A. P. Oron, D. Li, S. R. Riddell, J. R. Park and M. C. Jensen: Intent-to-treat leukemia remission by CD19 CAR T cells of defined formulation and dose in children and young adults. Blood, 129(25), 3322-3331 (2017) doi:10.1182/blood-2017-02-769208

166. C. M. Rooney, C. A. Smith, C. Y. Ng, S. K. Loftin, J. W. Sixbey, Y. Gan, D. K. Srivastava, L. C. Bowman, R. A. Krance, M. K. Brenner and H. E. Heslop: Infusion of cytotoxic T cells for the prevention and treatment of Epstein-Barr virus-induced lymphoma in allogeneic transplant recipients. Blood, 92(5), 1549-55 (1998)

167. K. S. Peggs, S. Verfuerth, A. Pizzey, N. Khan, M. Guiver, P. A. Moss and S. Mackinnon: Adoptive cellular therapy for early cytomegalovirus infection after allogeneic stem-cell transplantation with virus-specific T-cell lines. Lancet, 362(9393), 1375-7 (2003) doi:10.1016/s0140-6736(03)14634$\mathrm{x}$

168. A. M. Leen, G. D. Myers, U. Sili, M. H. Huls, H. Weiss, K. S. Leung, G. Carrum, R. A. Krance, C. C. Chang, J. J. Molldrem, A. P. Gee, M. K. Brenner, H. E. Heslop, C. M. Rooney and C. M. Bollard: Monoculture-derived $\mathrm{T}$ lymphocytes specific for multiple viruses expand and produce clinically relevant effects in immunocompromised individuals. Nat Med, 12(10), 1160-6 (2006) doi:10.1038/nm1475

169. E. Doubrovina, B. Oflaz-Sozmen, S. E. Prockop, N. A. Kernan, S. Abramson, J. TeruyaFeldstein, C. Hedvat, J. F. Chou, G. Heller, J. N. Barker, F. Boulad, H. Castro-Malaspina, D. George, A. Jakubowski, G. Koehne, E. B. Papadopoulos, A. Scaradavou, T. N. Small, R. Khalaf, J. W. Young and R. J. O'Reilly: Adoptive immunotherapy with unselected or EBV-specific T cells for biopsy-proven EBV+ lymphomas after allogeneic hematopoietic cell transplantation. Blood, 119(11), 2644-56 (2012) doi:10.1182/blood-2011-08-371971 
170. H. E. Heslop, K. S. Slobod, M. A. Pule, G. A. Hale, A. Rousseau, C. A. Smith, C. M. Bollard, H. Liu, M. F. Wu, R. J. Rochester, P. J. Amrolia, J. L. Hurwitz, M. K. Brenner and C. M. Rooney: Longterm outcome of EBV-specific T-cell infusions to prevent or treat EBV-related lymphoproliferative disease in transplant recipients. Blood, 115(5), 925-35 (2010) doi:10.1182/blood-2009-08-239186

171. J. N. Kochenderfer, M. E. Dudley, R. O. Carpenter, S. H. Kassim, J. J. Rose, W. G. Telford, F. T. Hakim, D. C. Halverson, D. H. Fowler, N. M. Hardy, A. R. Mato, D. D. Hickstein, J. C. GeaBanacloche, S. Z. Pavletic, C. Sportes, I. Maric, S. A. Feldman, B. G. Hansen, J. S. Wilder, B. Blacklock-Schuver, B. Jena, M. R. Bishop, R. E. Gress and S. A. Rosenberg: Donor-derived CD19targeted $\mathrm{T}$ cells cause regression of malignancy persisting after allogeneic hematopoietic stem cell transplantation. Blood, 122(25), 4129-39 (2013) doi:10.1182/blood-2013-08-519413

172. B. Afzali, R. I. Lechler and M. P. Hernandez-Fuentes: Allorecognition and the alloresponse: clinical implications. Tissue Antigens, 69(6), 545-56 (2007) doi:10.1111/j.1399-0039.2007.00834.x

173. E. E. Perez, J. Wang, J. C. Miller, Y. Jouvenot, K. A. Kim, O. Liu, N. Wang, G. Lee, V. V. Bartsevich, Y. L. Lee, D. Y. Guschin, I. Rupniewski, A. J. Waite, C. Carpenito, R. G. Carroll, J. S. Orange, F. D. Urnov, E. J. Rebar, D. Ando, P. D. Gregory, J. L. Riley, M. C. Holmes and C. H. June: Establishment of HIV-1 resistance in CD4+ T cells by genome editing using zinc-finger nucleases. Nat Biotechnol, 26(7), 808-16 (2008) doi:10.1038/nbt1410

174. J. C. Miller, S. Tan, G. Qiao, K. A. Barlow, J. Wang, D. F. Xia, X. Meng, D. E. Paschon, E. Leung, S. J. Hinkley, G. P. Dulay, K. L. Hua, I. Ankoudinova, G. J. Cost, F. D. Urnov, H. S. Zhang, M. C. Holmes, L. Zhang, P. D. Gregory and E. J. Rebar: A TALE nuclease architecture for efficient genome editing. Nat Biotechnol, 29(2), 143-8 (2011) doi:10.1038/nbt.1755

175. B. D. Sather, G. S. Romano Ibarra, K. Sommer, G. Curinga, M. Hale, I. F. Khan, S. Singh, Y. Song, K. Gwiazda, J. Sahni, J. Jarjour, A. Astrakhan, T. A. Wagner, A. M. Scharenberg and D. J. Rawlings: Efficient modification of CCR5 in primary human hematopoietic cells using a megaTAL nuclease and AAV donor template. Sci Transl Med, 7(307), 307ra156 (2015) doi:10.1126/scitranslmed.aac5530

176. M. J. Osborn, B. R. Webber, F. Knipping, C. L. Lonetree, N. Tennis, A. P. DeFeo, A. N. McElroy, C. G. Starker, C. Lee, S. Merkel, T. C. Lund, K. S. Kelly-Spratt, M. C. Jensen, D. F. Voytas, C. von Kalle, M. Schmidt, R. Gabriel, K. L. Hippen, J. S. Miller, A. M. Scharenberg, J. Tolar and B. R. Blazar: Evaluation of TCR Gene Editing Achieved by TALENs, CRISPR/Cas9, and megaTAL Nucleases. Mol Ther, 24(3), 570-81 (2016) doi:10.1038/mt.2015.197

177. L. Cong, F. A. Ran, D. Cox, S. Lin, R. Barretto, N. Habib, P. D. Hsu, X. Wu, W. Jiang, L. A. Marraffini and F. Zhang: Multiplex genome engineering using CRISPR/Cas systems. Science, 339(6121), 819-23 (2013) doi:10.1126/science.1231143

178. H. Torikai, A. Reik, P. Q. Liu, Y. Zhou, L. Zhang, S. Maiti, H. Huls, J. C. Miller, P. Kebriaei, B. Rabinovich, D. A. Lee, R. E. Champlin, C. Bonini, L. Naldini, E. J. Rebar, P. D. Gregory, M. C. Holmes and L. J. Cooper: A foundation for universal T-cell based immunotherapy: T cells engineered to express a CD19-specific chimeric-antigen-receptor and eliminate expression of endogenous TCR. Blood, 119(24), 5697-705 (2012) doi:10.1182/blood-2012-01-405365

179. J. Ren and Y. Zhao: Advancing chimeric antigen receptor T cell therapy with CRISPR/Cas9. Protein Cell, 8(9), 634-643 (2017) doi:10.1007/s13238-017-0410-x

180. N. Singh, J. Shi, C. H. June and M. Ruella: Genome-Editing Technologies in Adoptive T Cell Immunotherapy for Cancer. Curr Hematol Malig Rep, 12(6), 522-529 (2017) doi:10.1007/s11899-0170417-7

181. J. Eyquem, J. Mansilla-Soto, T. Giavridis, S. J. van der Stegen, M. Hamieh, K. M. Cunanan, A. Odak, M. Gonen and M. Sadelain: Targeting a CAR to the TRAC locus with CRISPR/Cas9 enhances tumour rejection. Nature, 543(7643), 113-117 (2017) doi:10.1038/nature21405

182. H. Torikai, A. Reik, F. Soldner, E. H. Warren, C. Yuen, Y. Zhou, D. L. Crossland, H. Huls, N. Littman, Z. Zhang, S. S. Tykodi, P. Kebriaei, D. A. Lee, J. C. Miller, E. J. Rebar, M. C. Holmes, R. Jaenisch, R. E. Champlin, P. D. Gregory and L. J. Cooper: Toward eliminating HLA class I expression to generate universal cells from allogeneic donors. Blood, 122(8), 1341-9 (2013) doi:10.1182/blood2013-03-478255

183. J. Ren, X. Zhang, X. Liu, C. Fang, S. Jiang, C. H. June and Y. Zhao: A versatile system for rapid multiplex genome-edited CAR T cell generation. Oncotarget, 8(10), 17002-17011 (2017) doi:10.18632/oncotarget.15218 
184. G. G. Gornalusse, R. K. Hirata, S. E. Funk, L. Riolobos, V. S. Lopes, G. Manske, D. Prunkard, A. G. Colunga, L. A. Hanafi, D. O. Clegg, C. Turtle and D. W. Russell: HLA-E-expressing pluripotent stem cells escape allogeneic responses and lysis by NK cells. Nat Biotechnol, 35(8), 765-772 (2017) doi:10.1038/nbt.3860

185. C. Jandus, K. F. Boligan, O. Chijioke, H. Liu, M. Dahlhaus, T. Demoulins, C. Schneider, M. Wehrli, R. E. Hunger, G. M. Baerlocher, H. U. Simon, P. Romero, C. Munz and S. von Gunten: Interactions between Siglec-7/9 receptors and ligands influence NK cell-dependent tumor immunosurveillance. J Clin Invest, 124(4), 1810-20 (2014) doi:10.1172/jci65899

186. C. J. Taylor, S. Peacock, A. N. Chaudhry, J. A. Bradley and E. M. Bolton: Generating an iPSC bank for HLA-matched tissue transplantation based on known donor and recipient HLA types. Cell Stem Cell, 11(2), 147-52 (2012) doi:10.1016/j.stem.2012.07.014

187. E. Vivier, E. Tomasello, M. Baratin, T. Walzer and S. Ugolini: Functions of natural killer cells. Nat Immunol, 9(5), 503-10 (2008) doi:10.1038/ni1582

188. G. Pittari, L. Vago, M. Festuccia, C. Bonini, D. Mudawi, L. Giaccone and B. Bruno: Restoring Natural Killer Cell Immunity against Multiple Myeloma in the Era of New Drugs. Front Immunol, 8, 1444 (2017) doi:10.3389/fimmu.2017.01444

189. D. L. Hermanson and D. S. Kaufman: Utilizing chimeric antigen receptors to direct natural killer cell activity. Front Immunol, 6, 195 (2015) doi:10.3389/fimmu.2015.00195

190. M. L. Saetersmoen, Q. Hammer, B. Valamehr, D. S. Kaufman and K. J. Malmberg: Off-theshelf cell therapy with induced pluripotent stem cell-derived natural killer cells. Semin Immunopathol (2018) doi:10.1007/s00281-018-0721-x

191. Z. B. Davis, M. Felices, M. R. Verneris and J. S. Miller: Natural Killer Cell Adoptive Transfer Therapy: Exploiting the First Line of Defense Against Cancer. Cancer J, 21(6), 486-91 (2015) doi:10.1097/ppo.0000000000000156

192. A. Romanski, C. Uherek, G. Bug, E. Seifried, H. Klingemann, W. S. Wels, O. G. Ottmann and T. Tonn: CD19-CAR engineered NK-92 cells are sufficient to overcome NK cell resistance in B-cell malignancies. J Cell Mol Med, 20(7), 1287-94 (2016) doi:10.1111/jcmm.12810

193. A. Q. Gomes, D. S. Martins and B. Silva-Santos: Targeting gammadelta T lymphocytes for cancer immunotherapy: from novel mechanistic insight to clinical application. Cancer Res, 70(24), 10024-7 (2010) doi:10.1158/0008-5472.can-10-3236

194. J. P. Fisher, J. Heuijerjans, M. Yan, K. Gustafsson and J. Anderson: gammadelta T cells for cancer immunotherapy: A systematic review of clinical trials. Oncoimmunology, 3(1), e27572 (2014) doi:10.4161/onci.27572

195. N. Daniele, M. C. Scerpa, M. Caniglia, M. E. Bernardo, C. Rossi, C. Ciammetti, G. Palumbo, F. Locatelli, G. Isacchi and F. Zinno: Transplantation in the onco-hematology field: focus on the manipulation of alphabeta and gammadelta T cells. Pathol Res Pract, 208(2), 67-73 (2012) doi:10.1016/j.prp.2011.10.006

196. Y. Hu, Q. Cui, C. Luo, Y. Luo, J. Shi and H. Huang: A promising sword of tomorrow: Human gammadelta T cell strategies reconcile allo-HSCT complications. Blood Rev, 30(3), 179-88 (2016) doi:10.1016/j.blre.2015.11.002

197. L. S. Lamb, Jr., P. Musk, Z. Ye, F. van Rhee, S. S. Geier, J. J. Tong, K. M. King and P. J. Henslee-Downey: Human gammadelta(+) T lymphocytes have in vitro graft vs leukemia activity in the absence of an allogeneic response. Bone Marrow Transplant, 27(6), 601-6 (2001) doi:10.1038/sj.bmt.1702830

198. D. C. Deniger, K. Switzer, T. Mi, S. Maiti, L. Hurton, H. Singh, H. Huls, S. Olivares, D. A. Lee, R. E. Champlin and L. J. Cooper: Bispecific T-cells expressing polyclonal repertoire of endogenous gammadelta T-cell receptors and introduced CD19-specific chimeric antigen receptor. Mol Ther, 21(3), 638-47 (2013) doi:10.1038/mt.2012.267

199. A. Capsomidis, G. Benthall, H. H. Van Acker, J. Fisher, A. M. Kramer, Z. Abeln, Y. Majani, T. Gileadi, R. Wallace, K. Gustafsson, B. Flutter and J. Anderson: Chimeric Antigen Receptor-Engineered Human Gamma Delta T Cells: Enhanced Cytotoxicity with Retention of Cross Presentation. Mol Ther, 26(2), 354-365 (2018) doi:10.1016/j.ymthe.2017.12.001

200. A. B. Pillai, T. I. George, S. Dutt, P. Teo and S. Strober: Host NKT cells can prevent graftversus-host disease and permit graft antitumor activity after bone marrow transplantation. J Immunol, 178(10), 6242-51 (2007) 
201. A. Heczey, D. Liu, G. Tian, A. N. Courtney, J. Wei, E. Marinova, X. Gao, L. Guo, E. Yvon, J. Hicks, H. Liu, G. Dotti and L. S. Metelitsa: Invariant NKT cells with chimeric antigen receptor provide a novel platform for safe and effective cancer immunotherapy. Blood, 124(18), 2824-33 (2014) doi:10.1182/blood-2013-11-541235

202. V. Leuci, G. M. Casucci, G. Grignani, R. Rotolo, U. Rossotti, E. Vigna, L. Gammaitoni, G. Mesiano, E. Fiorino, C. Donini, A. Pisacane, L. D. Ambrosio, Y. Pignochino, M. Aglietta, A. Bondanza and D. Sangiolo: CD44v6 as innovative sarcoma target for CAR-redirected CIK cells. Oncoimmunology, 7(5), e1423167 (2018) doi:10.1080/2162402x.2017.1423167

\section{Key words}

Chimeric antigen receptors T cells, CAR T cell therapy, adoptive immunotherapy

\section{Send correspondence to:}

Dr. Marta Coscia, Division of Hematology, University of Torino, Azienda Ospedaliero-Universitaria Città della Salute e della Scienza di Torino, via Genova 3, 10126 Torino, Italy. Phone Number: +390116336728; Fax Number: +390116963737; e-mail address: marta.coscia@unito.it

\section{Figure legend}

Figure 1. Schematic structure of chimeric antigen receptor (CAR). First generation CAR contains the single chain variable region ( $\mathrm{scFv}$ ) derived from a monoclonal antibody, the $\mathrm{T}$ cell receptor transmembrane domain, and an intracellular signaling domain of CD3 zeta chain. Second generation CAR contains a single co-stimulatory domain (CD28 or 4-1BB), whereas the third generation CAR contains two or more co-stimulatory domains (e.g. CD28 and 4-1BB). The fourth generation CAR is modified to express a molecule enhancing $\mathrm{T}$ cell function (e.g. cytokines or immunomodulatory molecules) or a controllable on-off switch (armored CAR).

\section{Running title}

CAR T cell adoptive immunotherapy in cancer 
Figure 1.

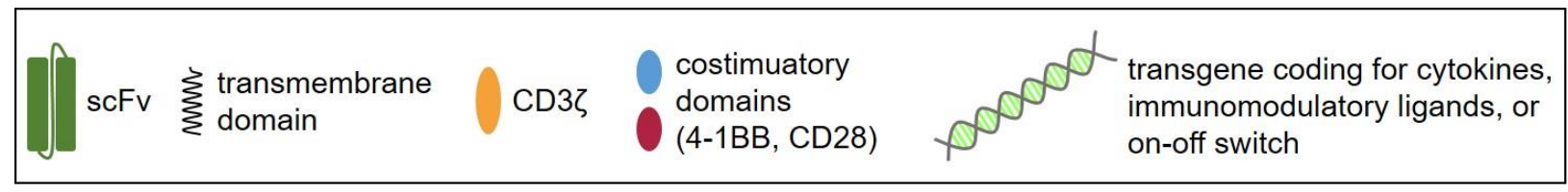

$1^{\text {st }}$ generation

$2^{\text {nd }}$ generation

$3^{\text {rd }}$ generation

$4^{\text {th }}$ generation

$\int$

$\int_{3}^{1}$

$\sqrt{3}$

("armored")

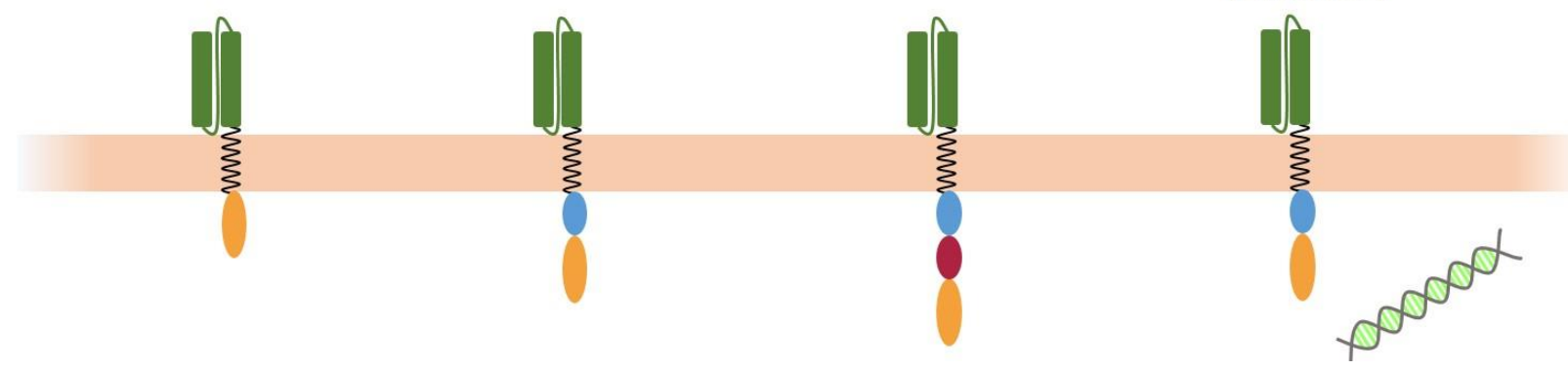


Table 1. Anti-CD19 CAR T constructs.

\begin{tabular}{|c|c|c|c|c|}
\hline & $\begin{array}{c}\text { Tisagenlecleucel } \\
\text { (CTL019, } \\
\text { Kymriah®) }\end{array}$ & $\begin{array}{c}\text { Axicabtagene } \\
\text { Ciloleucel } \\
\text { (KTE-C19, } \\
\left.\text { Yescarta }{ }^{8}\right)\end{array}$ & $\begin{array}{c}\text { Lisocabtagene } \\
\text { Maraleucel } \\
\text { (JCAR017) }\end{array}$ & UCART19 \\
\hline Construct & 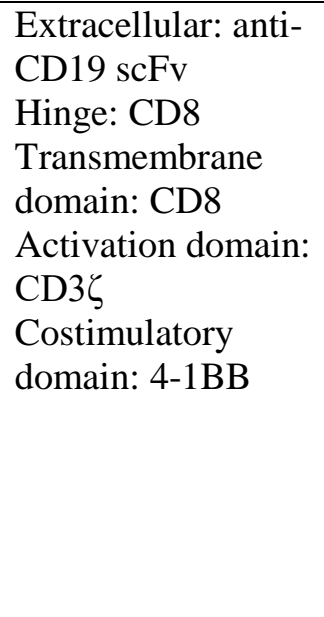 & 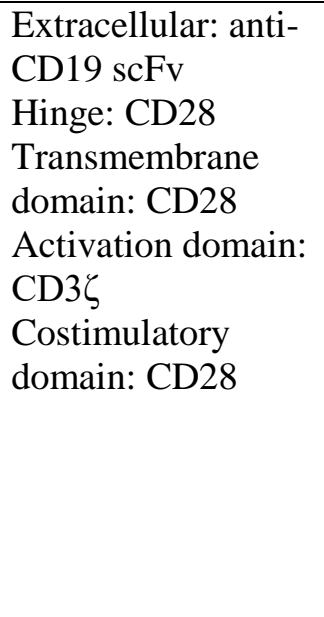 & 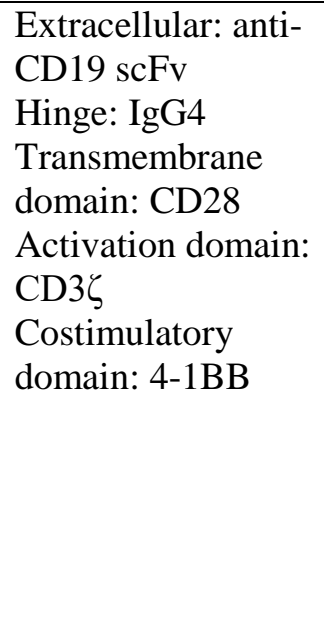 & 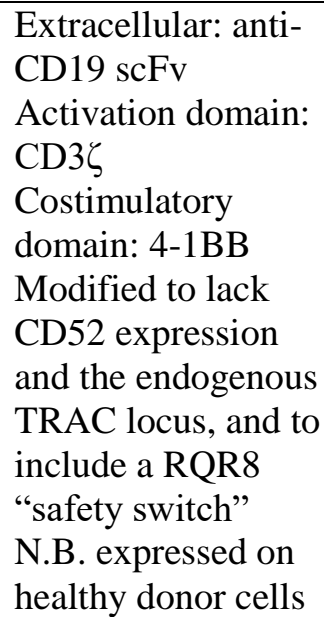 \\
\hline $\begin{array}{l}\text { Current } \\
\text { status }\end{array}$ & $\begin{array}{l}\text { Approved } \\
\text { (US/Europe): } \\
\text { - refractory B-cell } \\
\text { precursor ALL in } \\
\text { second relapse or } \\
\text { beyond ( } 25 \text { years) } \\
\text { - large B-cell } \\
\text { lymphoma R/R to } \\
\geq 2 \text { lines of therapy } \\
\text { (adults) }\end{array}$ & $\begin{array}{l}\text { Approved } \\
\text { (US/Europe): } \\
\text { - large B-cell } \\
\text { lymphoma R/R to } \\
\geq 2 \text { lines of therapy } \\
\text { (adults)* }\end{array}$ & Under development & Under development \\
\hline $\begin{array}{l}\text { Main } \\
\text { clinical } \\
\text { references }\end{array}$ & $\begin{array}{l}\text { - Phase II, R/R B- } \\
\text { cell ALL } \\
\text { (pediatric/young } \\
\text { adults). ORR 81\%, } \\
\text { CR 60\%, CRi 21\% } \\
\text { (15). } \\
\text { - Phase II, R/R } \\
\text { DLBCL and FL. 3- } \\
\text { month ORR 64\%, } \\
\text { 6-month CR 57\% } \\
\text { (16). } \\
\text { - Multicenter phase } \\
\text { II, R/R DLBCL } \\
\text { (JULIET). ORR } \\
\text { 53\%, CR 39\%, CRi } \\
\text { 14\% (17). } \\
\text { - Phase I, R/R CLL. } \\
\text { ORR 57\%, CR29\% } \\
\text { (18). }\end{array}$ & $\begin{array}{l}\text { - Phase II, R/R } \\
\text { DLBCL, PMBCL, } \\
\text { and transformed FL } \\
\text { (ZUMA-1). ORR } \\
82 \%, \text { CR } 54 \%(23) . \\
\text { - Phase I/II , R/R } \\
\text { B-precursor ALL } \\
\text { (ZUMA-3). ORR } \\
82 \%, \text { CR or CRi } \\
73 \%(24) .\end{array}$ & $\begin{array}{l}\text { - Phase I, R/R B } \\
\text { cell lymphomas } \\
\text { (TRANSCEND- } \\
\text { 001). DLBCL } \\
\text { cohort 3-month } \\
\text { ORR 49\%, 3-month } \\
\text { CR 40\% (28). }\end{array}$ & $\begin{array}{l}\text { - Phase I, high risk } \\
\text { R/R B-cell ALL } \\
\text { (pediatric). CR/CRi } \\
5 / 5 \text { (30). }\end{array}$ \\
\hline
\end{tabular}

* including in US DLBCL not otherwise specified, PMBCL, high grade B-cell lymphoma, and DLBCL arising from FL, in whereas in Europe only DLBCL and PMBCL.

Abbreviations:

ALL: acute lymphoblastic leukemia; CLL: chronic lymphocytic leukemia; CR: complete response; CRi: CR with incomplete hematologic recovery; DLBCL: diffuse large B-cell lymphoma; FL: follicular lymphoma; ORR: overall response rate; PMBCL: primary mediastinal B-cell lymphoma; PR: partial response; R/R: relapsed or refractory. 
Table 2. Alternative targets for CAR T cells.

\begin{tabular}{|c|c|c|c|c|c|c|}
\hline Target & Construct details & Patient population & Results & Location & NCT identifier & Reference \\
\hline $\mathrm{CD} 20$ & $\begin{array}{l}\mathrm{CD} 28 / 4-1 \mathrm{BB} / \mathrm{CD} 3 \zeta \\
\text { plasmid electroporation }\end{array}$ & $\begin{array}{l}\mathrm{R} / \mathrm{R} \mathrm{CD} 20+\text { indolent } \\
\mathrm{B} \text {-cell NHL or MCL }\end{array}$ & $\begin{array}{l}9 \text { patients treated (8 FL and } \\
1 \mathrm{MCL}): 2 \text { NED, } 1 \mathrm{PR}, 6 \\
\text { SD (2 PR) }\end{array}$ & $\begin{array}{l}\text { Fred Hutchinson Cancer Research } \\
\text { Center, Seattle, USA }\end{array}$ & NCT00012207 & (33) \\
\hline $\mathrm{CD} 20$ & $\begin{array}{l}\text { CD28/4-1BB/CD3 } \zeta, \\
\text { plasmid electroporation }\end{array}$ & $\begin{array}{l}\text { R/R CD20+ indolent } \\
\text { B-cell NHL or MCL }\end{array}$ & $\begin{array}{l}4 \text { patients treated (3 MCL } \\
\text { and } 1 \mathrm{FL}): 1 \mathrm{PR}, 2 \mathrm{SD}(\mathrm{CR})\end{array}$ & $\begin{array}{l}\text { Fred Hutchinson Cancer Research } \\
\text { Center, Seattle, USA }\end{array}$ & NCT00621452 & (34) \\
\hline $\mathrm{CD} 22$ & $\begin{array}{l}4-1 \mathrm{BB} / \mathrm{CD} 3 \zeta \text {, lentiviral } \\
\text { vector }\end{array}$ & R/R B-cell ALL & $\begin{array}{l}21 \text { patients treated: } 12 \mathrm{CR} \text {; } \\
\text { median DOR } 6 \text { months }\end{array}$ & $\begin{array}{l}\text { National Institutes of Health, } \\
\text { Bethesda, USA }\end{array}$ & NCT02315612 & $(35)$ \\
\hline $\mathrm{k}$ light chain & $\begin{array}{l}\mathrm{CD} 28 / \mathrm{CD} 3 \zeta \text {, retroviral } \\
\text { vector }\end{array}$ & $\begin{array}{l}\text { R/R NHL/CLL or } \\
\text { MM }\end{array}$ & $\begin{array}{l}16 \text { patients: } 2 / 9 \text { CR and } 1 / 9 \\
\text { PR in NHL/CLL; } 4 / 7 \text { SD in } \\
\text { MM }\end{array}$ & $\begin{array}{l}\text { Baylor College of Medicine, } \\
\text { Houston Methodist Hospital and } \\
\text { Texas Children's Hospital, } \\
\text { Houston, USA }\end{array}$ & NCT00881920 & $(36)$ \\
\hline BCMA & 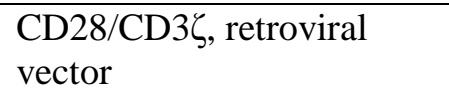 & $\mathrm{R} / \mathrm{R} \mathrm{MM}$ & $\begin{array}{l}16 \text { patients: } 81 \% \text { ORR, } 63 \% \\
\text { VGPR or CR }\end{array}$ & $\begin{array}{l}\text { National Institutes of Health, } \\
\text { Bethesda, USA }\end{array}$ & NCT02215967 & $(49)$ \\
\hline BCMA & $\begin{array}{l}4-1 \mathrm{BB} / \mathrm{CD} 3 \zeta \text {, lentiviral } \\
\text { vector }\end{array}$ & Refractory MM & $\begin{array}{l}21 \text { treated patients: } 13 / 20 \\
\text { ORR ( } 8 / 20 \text { PR or better) }\end{array}$ & University of Pennsylvania, USA & NCT02546167 & $(50)$ \\
\hline BCMA & $\begin{array}{l}4-1 \mathrm{BB} / \mathrm{CD} 3 \zeta \text {, lentiviral } \\
\text { vector }\end{array}$ & $\mathrm{R} / \mathrm{R} \mathrm{MM}$ & $\begin{array}{l}21 \text { patients treated (18 } \\
\text { evaluable for response): } \\
\text { ORR } 89 \%\end{array}$ & $\begin{array}{l}\text { National Institutes of Health } \\
\text { Clinical Center, Bethesda, MD }\end{array}$ & NCT02658929 & $(51)$ \\
\hline CD30 & $\begin{array}{l}4-1 \mathrm{BB} / \mathrm{CD} 3 \zeta \text {, lentiviral } \\
\text { vector }\end{array}$ & $\mathrm{R} / \mathrm{R} \mathrm{HL}$ & $\begin{array}{l}18 \text { patients treated: } 7 \mathrm{PR} \\
\text { and } 6 \mathrm{SD}\end{array}$ & $\begin{array}{l}\text { Chinese PLA General Hospital, } \\
\text { Beijing, China }\end{array}$ & NCT02259556 & (64) \\
\hline CD30 & $\begin{array}{l}\mathrm{CD} 28 / \mathrm{CD} 3 \zeta \text {, retroviral } \\
\text { vector }\end{array}$ & $\mathrm{R} / \mathrm{R} \mathrm{HL}$ or ALCL & $\begin{array}{l}7 \text { patients treated with HL: } 2 \\
\text { CR and } 3 \text { transient SD; } \\
2 \text { patients treated with } \\
\text { ALCL: } 1 \text { CR }\end{array}$ & $\begin{array}{l}\text { Baylor College of Medicine, } \\
\text { Houston, Texas, USA. }\end{array}$ & NCT01316146 & $(65)$ \\
\hline CD123 & 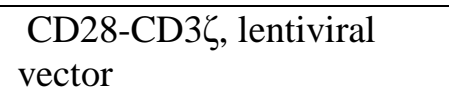 & R/R AML, BPDCN & $\begin{array}{l}7 \text { patient treated: } 3 \text { CR, } 1 \\
\text { MLFS, } 2 \text { PR, } 1 \text { PD }\end{array}$ & City of Hope, Duarte, USA & NCT02159495 & $(86)$ \\
\hline CD123 & $\begin{array}{l}\text { TCR/4-1BB, electroporated } \\
\text { RNA }\end{array}$ & R/R AML & $\begin{array}{l}5 \text { patients treated: no } \\
\text { response }\end{array}$ & University of Pennsylvania, USA & NCT02623582 & $(70)$ \\
\hline CD123 & $\begin{array}{l}\text { CD28/CD137/CD27/CD3fi } \\
\text { Casp9 } \\
\text { (4th generation) }\end{array}$ & $\mathrm{R} / \mathrm{R}$ AML & 1 patient treated: $P R$ & $\begin{array}{l}\text { The First Affiliated Hospital of } \\
\text { Zhejiang University, China }\end{array}$ & NCT03125577 & $(85)$ \\
\hline
\end{tabular}




\begin{tabular}{|c|c|c|c|c|c|c|}
\hline CD33 & 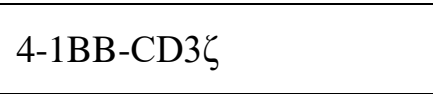 & R/R AML & $\begin{array}{l}1 \text { patient treated: short } \\
\text { lasting PR }\end{array}$ & PLA Hospital, Beijing, China & NCT01864902 & (84) \\
\hline LeY & $\mathrm{CD} 28-\mathrm{CD} 3 \zeta$ & R/R AML & $\begin{array}{l}4 \text { patients treated: short } \\
\text { lasting PR/SD }\end{array}$ & $\begin{array}{l}\text { Peter MacCallum Cancer } \\
\text { Centre, Melbourne, Australia }\end{array}$ & NCT01716364 & $(82)$ \\
\hline NKG2D & $\mathrm{CD} 3 \zeta$ plus DAP10 signal & $\begin{array}{l}\text { R/R AML, MDS, } \\
\text { MM }\end{array}$ & $\begin{array}{l}6 \mathrm{R} / \mathrm{R} \text { AML or MDS } \\
\text { treated: no response }\end{array}$ & $\begin{array}{l}\text { Dana-Farber Cancer Institute, } \\
\text { Boston, USA }\end{array}$ & NCT02203825 & $(56)$ \\
\hline NKG2D & $\mathrm{CD} 3 \zeta$ plus DAP10 signal & $\begin{array}{l}\text { R/R AML, MM, } \\
\text { epitelial cancers }\end{array}$ & 1 AML treated: CR & $\begin{array}{l}\text { Multiple sites in Belgium and } \\
\text { USA }\end{array}$ & NCT 03018405 & $(90)$ \\
\hline CLL1-CD33 & NA & R/R AML or MDS & 1 AML treated: CR & $\begin{array}{l}\text { The General Hospital of Western } \\
\text { Theater Command, China }\end{array}$ & NCT03795779 & $(91)$ \\
\hline CEA & $\begin{array}{l}\mathrm{CD} 28-\mathrm{CD} 3 \zeta \text { (intra-arterial } \\
\text { administration) }\end{array}$ & $\begin{array}{l}\text { Colorectal } \\
\text { carcinoma }\end{array}$ & 6 patients treated: $1 \mathrm{SD}$ & $\begin{array}{l}\text { Roger Williams Medical Center, } \\
\text { Providence, USA }\end{array}$ & NCT00673322 & (108) \\
\hline CEA & $\mathrm{CD} 28-\mathrm{CD} 3 \zeta$ & $\begin{array}{l}\text { Colorectal } \\
\text { carcinoma }\end{array}$ & 10 patients treated: $7 \mathrm{SD}$ & $\begin{array}{l}\text { Southwest Hospital, Third } \\
\text { Military Medical University, } \\
\text { China }\end{array}$ & NCT03267173 & (137) \\
\hline CEA & $\mathrm{CD} 3 \zeta$ & $\begin{array}{l}\text { CEA positve } \\
\text { malignancies }\end{array}$ & No response & $\begin{array}{l}\text { The Christie NHS Foundation } \\
\text { Trust, Manchester, UK }\end{array}$ & NCT01212887 & (101) \\
\hline HER-2 & $\mathrm{CD} 28-\mathrm{CD} 3 \zeta$ & Sarcomas & $\begin{array}{l}17 \text { patients treated: } 4 \text { SD. } \\
\text { After lymphodepletion, } 6 \\
\text { patients treated: } 1 \mathrm{CR}\end{array}$ & $\begin{array}{l}\text { Baylor College of Medicine, } \\
\text { Houston, USA }\end{array}$ & NCT00902044 & $(134,135)$ \\
\hline HER-2 & 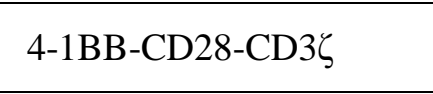 & $\begin{array}{l}\text { Colorectal } \\
\text { carcinoma }\end{array}$ & Fatal CRS in 1 patient & $\begin{array}{l}\text { National Cancer Institute, } \\
\text { Bethesda, USA }\end{array}$ & NA & (99) \\
\hline HER-2 & 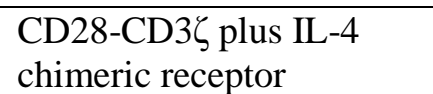 & HNSCC & $\begin{array}{l}13 \text { patients treated: disease } \\
\text { control in } 9\end{array}$ & $\begin{array}{l}\text { Guy's and St Thomas' Hospitals, } \\
\text { London, UK }\end{array}$ & NCT01818323 & (140) \\
\hline HER-2 & $\mathrm{CD} 28-\mathrm{CD} 3 \zeta$ & Glioblastoma & $\begin{array}{l}17 \text { patients treated: } 1 \text { PR, } 7 \\
\text { SD }\end{array}$ & $\begin{array}{l}\text { Baylor College of Medicine, } \\
\text { Houston, USA }\end{array}$ & NCT01109095 & (143) \\
\hline CAIX & NA & $\begin{array}{l}\text { Renal cell } \\
\text { carcinoma }\end{array}$ & No response & $\begin{array}{l}\text { Erasmus University Medical } \\
\text { Center, The Netherlands }\end{array}$ & NA & (100) \\
\hline Mesothelin & $\begin{array}{l}\text { 4-1BB-CD3 } \zeta \\
\text { electroporated RNA }\end{array}$ & Pancreatic cancer & 6 patients treated: 2 SD & University of Pennsylvania, USA & NCT03323944 & (105) \\
\hline GD-2 & $\mathrm{CD} 28-\mathrm{CD} 3 \zeta-\mathrm{OX} 40$ & Neuroblastoma & 11 patients treated: $3 \mathrm{CR}$ & $\begin{array}{l}\text { Baylor College of Medicine, } \\
\text { Huston, USA }\end{array}$ & NCT00085930 & (136) \\
\hline GPC3 & NA & $\begin{array}{l}\text { Hepatocellular } \\
\text { carcinoma }\end{array}$ & $\begin{array}{l}13 \text { patients treated: } 1 \mathrm{PR}, 3 \\
\text { SD }\end{array}$ & $\begin{array}{l}\text { Shanghai Jiaotong University, } \\
\text { China }\end{array}$ & NCT02395250 & (138) \\
\hline
\end{tabular}




\begin{tabular}{|c|c|c|c|c|c|c|}
\hline CD133 & CD137-CD3 $\zeta$ & $\begin{array}{l}\text { Epithelial } \\
\text { malignacies }\end{array}$ & $\begin{array}{l}23 \text { treated patients: } 3 \text { PR, } 14 \\
\text { SD }\end{array}$ & $\begin{array}{l}\text { PLA General Hospital, Beijing, } \\
\text { China. }\end{array}$ & NCT02541370 & (139) \\
\hline EGFRvII & $4-1 \mathrm{BB}-\mathrm{CD} 3 \zeta$ & Glioblastoma & $\begin{array}{l}10 \text { patients treated: } 1 \\
\text { persistent SD }\end{array}$ & University of Pennsylvania, USA & NCT02209376 & $(142)$ \\
\hline IL-13R $\alpha 2$ & $\begin{array}{l}\text { 4-1BB-CD3 } \zeta \text { (intra- } \\
\text { cranial admnistration) }\end{array}$ & Glioblastoma & $\begin{array}{l}\text { Of the first } 3 \text { patients } \\
\text { treated: } 2 \mathrm{PR} \text {, then } 1 \mathrm{CR} \\
\text { reported }\end{array}$ & City of Hope, Duarte, USA & $\begin{array}{l}\text { NCT00730613/ } \\
\text { NCT02208362 }\end{array}$ & $(147,148)$ \\
\hline
\end{tabular}

Abbreviations:

CLL: chronic lymphocytic leukemia; MM: multiple myeloma; HL: Hodgkin lymphoma; ALCL: anaplastic large cell lymphoma; ALL: acute lymphoblastic leukemia; AML: acute myeloid leukemia; BPDCN: blastic plasmacytoid dendritic cell neoplasm; CR: complete response; CRS: cytokine release syndrome; DOR: duration of response; FL: follicular lymphoma; HL; Hodgkin lymphoma; HNSCC: head and neck squamous-cell carcinoma; MCL mantle cell lymphoma; MDS: myelodysplastic syndromes; MM: multiple myeloma; MLFS: morphologic leukemia free status; NED: no evidence of disease progression; NHL: non Hodgkin lymphoma; PD: progressive disease; R/R: relapsed or refractory PR: partial response; SD: stable disease; VGPR: very good partial response. 